\title{
Tornado Fragility and Risk Assessment of an Archetype Masonry School Building
}

\author{
Hassan Masoomi and John W. van de Lindt* \\ Dept. of Civil and Environmental Engineering, Colorado State University, Fort Collins, CO 80523, United States
}

\section{Abstract}

6 Tornadoes are a low-occurrence high-consequence hazard and not only threaten the life safety of

7 building occupants but have recently resulted in billions of dollars in direct and indirect damages

8 for single events. Design codes do not consider tornado loads for building and other structures

9 (with the exception of nuclear facilities) because the occurrence rate has historically been

10 considered too low. The advent of performance-based seismic design has revolutionized the

11 engineering thought process and as a result building owners can consider performance objectives

12 that enable a building to perform better in an extreme hazard than observed with current design

13 code. In this paper, the performance of a masonry school building subjected to tornado wind

14 loads is investigated using a fragility methodology. The tornado fragility assessment

15 methodology is described along with proposed damage states for consideration in loss

16 estimation. An array of masonry material types are considered based on the Masonry Standards

17 Joint Committee (MSJC) code to enable applicability of the fragilities developed herein for a

18 range of designs throughout the United States.

19 Keywords: Tornado; Risk Assessment; Fragility; Masonry; School building; Hazard Curve.

\section{1. Introduction}

\subsection{Tornado Risk Assessment}

23 Tornadoes are a low-occurrence high-consequence hazard and have resulted in billions of dollars

24 in direct and indirect damages for single events and continue to threaten life safety in many

25 regions of the United States [1]. While a number of studies have been conducted focusing on

\footnotetext{
${ }^{*}$ Corresponding author.

E-mail address: jwv@engr.colostate.edu
} 
tornado dynamics (e.g., [2]), tornado wind pressure distributions (e.g., [3, 4]), design of

27 structures for tornadoes (e.g., [5, 6]), and damage prediction for buildings in tornadoes (e.g., [7]);

28 there still remains a substantial dearth of tornado-risk-assessment in the general open literature.

29 Moreover, there is an extensive body of literature on seismic fragility analysis [8] and

30 vulnerability assessments in the case of strong straight-line winds (i.e. Hurricanes) [9, 10].

31 However, there are only several tornado risk assessment studies, which have focused on risk for

32 nuclear power plants [11] and other critical infrastructure but not typical buildings within

33 communities. Thus, in order to perform a community risk analysis for tornado hazard, a

34 significant body of research is needed to fill this dearth.

35 The low probability of occurrence of tornadoes has prevented consideration of tornado loads in

36 modern building codes, but this is changing as a result of deadly and damaging tornadoes over

37 the last five years (Tuscaloosa, 2011; Joplin, 2011; Moore, 2013). Although a number of studies

38 had been done on tornado-induced loads on buildings [12, 13], the data deficiency motivated

39 researchers to investigate tornado-induced forces on buildings [14, 15]. In this regard, tornado-

40 like vortices have been simulated and investigated in laboratories, including the VorTECH

41 simulator at Texas Tech University [16], the Iowa State University (ISU) simulator [14], and the

42 Wind Engineering, Energy and Environment (WindEEE) Dome at Western University [17]. At

43 ISU, Haan et al. [14] studied tornado-induced wind loads for a laboratory-simulated tornado and

44 compared them with the provisions of building codes. Their study revealed that tornadoes can

45 generate load coefficients greater than those prescribed by ASCE 7-05 [18] for straight-line wind

46 over open terrain. Based on the discussion by Kopp and Morrison [19] on the study done by

47 Haan et al. [14], it is clear that further studies are needed to investigate spatial correlation of

48 tornado loads on the building envelope, translation speed of the vortex, duration effects, and

49 changes to the internal pressure during a tornado, which were the main disagreements among the

50 researchers. Kikitsu et al. [20] strengthened the formula proposed by Simiu et al. [21], for

51 calculation of tornado-induced pressure, to consider the effect of both opening and leakage on

52 internal pressure. In fact, this proposed approach provided a better model for tornado loading;

53 however, additional studies would provide statistics for the parameters related to leakage and

54 opening in different types of buildings as well as other coefficients. 
55 Based on the work completed by van de Lindt et al. [6], tornado-induced loads can be calculated 56 by applying tornado coefficients to pressure coefficients using the common approach in ASCE 75710 [18]. Tornado coefficients used in this study are based on the study done by Haan et al. [14]. 58 Note that Haan et al. [14] used ASCE 7-05, but using ASCE 7-10 does not alter the values since 59 they are the same for both editions. Using this procedure, van de Lindt et al. [6] proposed a dual60 objective design philosophy to reduce damage for tornadoes in the EF0 to EF2 (Enhanced Fujita 61 scale [22]) range, and focus on life safety in tornadoes of higher intensity, i.e. EF3 to EF5. 62 Moreover, this method has been used in tornado risk analysis of wood-frame buildings [23, 24] and performance assessment of earthen masonry dwelling buildings [25].

\subsection{Schools in Tornado-Prone Regions}

65 Pressures caused by high wind speeds cause damage to buildings and other components making up community infrastructure. While all buildings are important, certain buildings capture the attention of communities because of their purpose. Some of these buildings are facilities such as emergency facilities, schools which host communities' children each day, and hospitals. According to the wind hazard map in ASCE 7-10 [18], the majority of the United States, including Tornado Alley and Dixie Alley, has a basic wind speed of $54 \mathrm{~m} / \mathrm{s}$ (120 mph) for school buildings (risk category III and IV buildings). This wind speed is for straight-line winds from a Derecho or hurricane, but in theory possess the same wind speed of an EF2 tornado, although strong tornado wind speeds have never been explicitly measured with enough quality for use in analysis. Tornado wind speeds for significant tornadoes have been measured only through mobile Doppler radar but not at ground level. Approximately 97 percent of all recorded tornadoes are rated as EF2 or below [26]. Tornadic winds produce an intensified mean flow and enhanced turbulence at ground level [27], and include a large static pressure drop and a vertical wind velocity component, which together may result in a higher level of damage, especially roof damage, than their straight-line wind counterpart corresponding to the same horizontal velocity.

80 However, this latter point is still a focus of on-going research around the world and lacks 81 consensus.

82 Therefore, at issue is that damage caused by an EF2 tornado is not consistent to that of a $54 \mathrm{~m} / \mathrm{s}$ 83 (120 mph) straight-line wind underscoring the fact that no design codes or guidance address 84 tornado-induced loads except those developed by the U.S. Nuclear Regulatory Commission (e.g. 
85 [11]) for reactor design. In fact, the wind pressures that tornadoes exert on a building were 86 shown in one study to be more than twice [14] the minimum pressures derived from building

87 codes, although as mentioned there has been disagreement amongst researchers to date on the 88 approach used during the scale experiments [19]. In general, most buildings including schools 89 will experience significant damage if they are in the path of a strong tornado because they have not been designed for this type of loading.

\subsection{Observed Damage to Schools from Tornadoes}

92 Over the years tornadoes have destroyed or severely damaged a significant number of schools, 93 resulting in injuries and fatalities. One well-known case was Xenia senior high school in Xenia,

94 Ohio in the United States (Figure 1) which was hit by an F5 tornado in 1974 [26]. The tornado 95 passed directly over the school. The enclosure walls failed on the west and south sides; roofs collapsed over the three long spans - the auditorium, the boys' gym, and the girls' gym; and the

97 lightweight roof was torn off by the extreme winds. St. Augustine elementary school in 98 Kalamazoo Michigan was hit by an F3 tornado in 1980 [26]. The magnitude of the damage to the school was severe enough that demolition was eventually required. The loadbearing west wall collapsed inward, and the east wall fell outward. The roof fell into the building when the walls collapsed. Slender unreinforced masonry walls and the long-span roof structure were determined to be hazardous elements of this type of construction during post-event inspection. Kelly 103 elementary school in Moore Oklahoma was hit by an F4 tornado in 1999 [26] to such an extent 104 that the remaining structure was demolished and the school was reconstructed. Roof-to-wall connections were sufficient for gravity loads, but could not bear the high uplift loads caused by the wind. Unreinforced masonry walls failed when the roof system lifted off and was removed by

107 tornado winds. Perhaps one of the most tragic school events occurred in the Enterprise, Alabama tornado in 2007 (EF4 tornado), when a school with unreinforced masonry walls and hollow-core concrete roof planks collapsed and eight student fatalities were reported [28]. On May 22, 2011,

110 an EF5 tornado struck Joplin, Missouri. In the path of the tornado, Joplin High School, Franklin 111 Technical Center, and Joplin East Middle School were extensively damaged while some other

112 schools sustained moderate to intense damages. Although Joplin High School was built in 1968 113 and Joplin East Middle School was built in 2009, their performance from the tornadic winds was 114 very similar [29, 30]. On May 20, 2013, Moore, Oklahoma, was impacted by an intense EF5 
115 tornado. The tornado struck Briarwood Elementary School, Plaza Towers Elementary School, 116 and Highland East Junior High School. Briarwood and Plaza Towers Elementary Schools 117 sustained enough damage to be considered a total loss, while for Highland East Junior High 118 School the primary damage during the tornado was to the gymnasium, and only minimal damage 119 occurred to the classroom building which was further away from tornado center. Moreover, 120 seven fatalities occurred in the Plaza Towers Elementary School when a hallway being used as a 121 place of refuge collapsed [31].

122 The study presented in this paper discusses performance of the building envelope, nonstructural, 123 and structural building systems of an archetype unreinforced masonry school building using a 124 tornado fragility analysis methodology and characterizes the resulting fragilities for components 125 into damage state fragility curves for the school building based on proposed building damage 126 states. The results can serve two major purposes: (1) they can be utilized to inform guidelines for 127 better design practices related to new and existing schools in tornado-prone regions, e.g. using 128 steel reinforcement with full grouting in all cells instead of unreinforced masonry construction, 129 and (2) the fragility curves developed herein can be used to be representative of masonry school 130 buildings in community risk and resilience assessment and improvement models. 

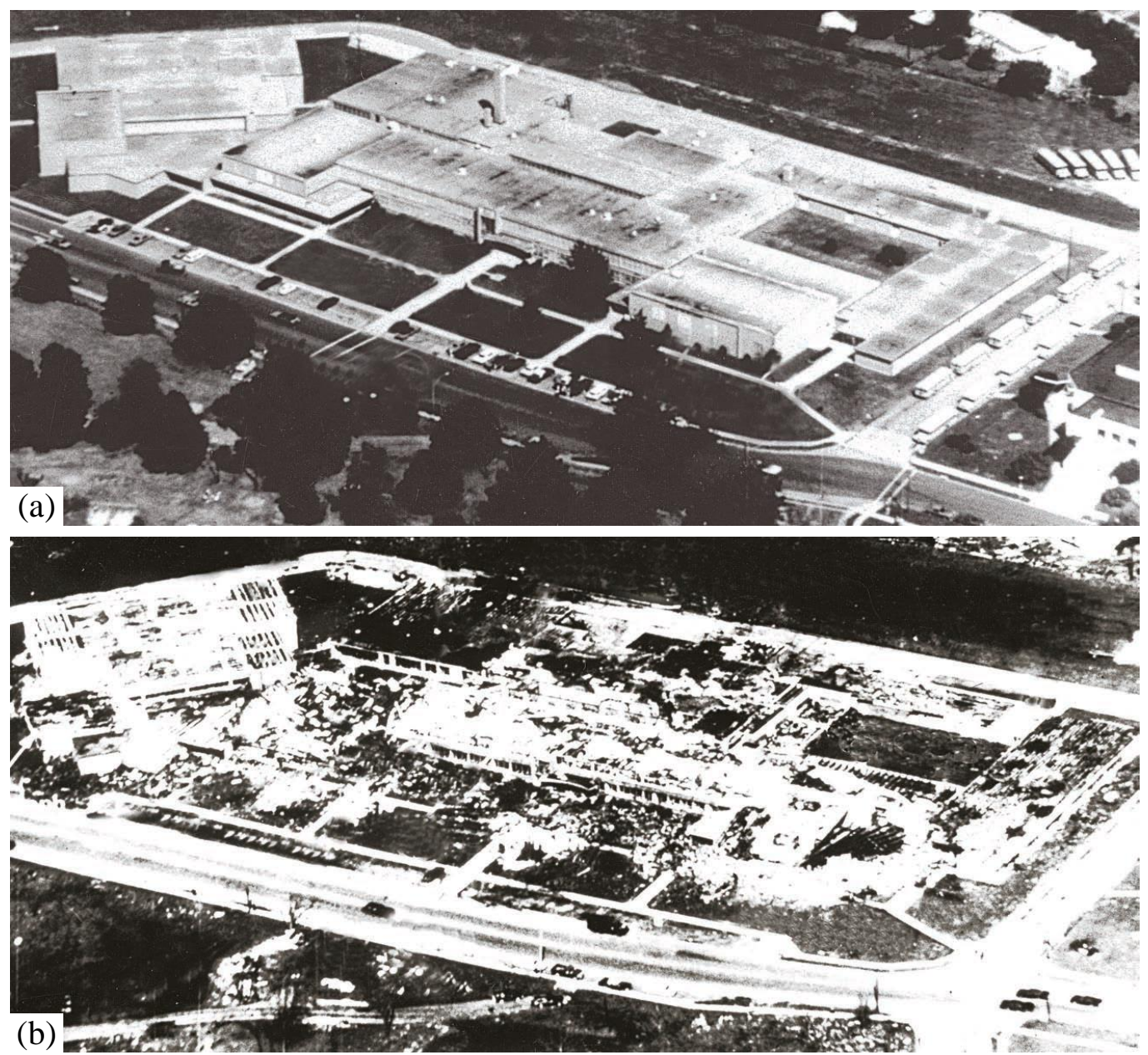

Figure 1. Xenia Senior High School, Xenia, Ohio: (a) before tornado, (b) after tornado (Excerpted from FEMA [26], photo credit: WERC, TEXAS TECH UNIVERSITY)

\section{2. Tornado Fragility Methodology}

\subsection{Fragility Modeling}

136 A fragility can be defined as a conditional probability of exceeding a specific amount of damage 137 as a function of an intensity measure [32]:

$138 \quad \operatorname{Fr}(x)=P[D(x) \geq R \mid I M=x]$

139 where $I M=$ random variable intensity measure describing the intensity of the demand on the

140 system (e.g., 3-s gust wind speed; earthquake spectral acceleration at the fundamental period of 141 the building, peak ground acceleration, etc.), $D(x)=$ demand on the system at intensity measure 142 of $x$, and $R=$ resistance of component or system. 
143 In this study, a probabilistic analysis of the system was performed using Monte Carlo Simulation

144 (MCS) to develop tornado fragility curves. This approach generates samples of random demand 145 and resistance variables from their specified distributions, or from statistical parameters of their

146 components, and evaluates whether wind-induced failure would occur. This procedure is 147 repeated for a range of wind speeds to complete the fragility curve and dependencies are 148 included as will be expanded on later.

149 For convenience and often a good statistical fit, a lognormal distribution is used to describe a 150 fragility (i.e., $\lambda_{R}$ and $\xi_{R}$ ) to model structural systems or their components [33]:

$151 \quad \operatorname{Fr}(x)=\Phi\left(\frac{\ln (x)-\lambda_{R}}{\xi_{R}}\right)$

152 in which $\Phi[]=$. standard normal cumulative distribution function, $x=$ intensity measure (i.e., 3-s 153 gust wind speed for tornado fragility curves), $\lambda_{R}=$ logarithmic median of resistance $R$ (in units 154 that are dimensionally consistent with demand), and $\xi_{R}=$ logarithmic standard deviation of 155 resistance $R$.

\subsection{Tornado Load Modeling}

157 The procedure discussed in ASCE 7-10 [18] for calculation of wind forces resulting from 158 straight-line winds have been extensively studied, and the equation for calculating velocity 159 pressure is:

160

$q_{z}=0.613 K_{z} K_{z t} K_{d} V^{2} \quad\left(\mathrm{~N} / \mathrm{m}^{2} ; V\right.$ in $\left.\mathrm{m} / \mathrm{s}\right)$

$q_{z}=0.00256 K_{z} K_{z t} K_{d} V^{2} \quad\left(\mathrm{lb} / \mathrm{ft}^{2} ; V\right.$ in $\left.\mathrm{mph}\right)$

162 where, $K_{z}=$ velocity pressure exposure coefficient, $K_{z t}=$ topographic factor, $K_{d}=$ wind 163 directionality factor, $V=$ basic wind speed, $q_{z}=$ velocity pressure calculated at height $z$, and $q_{h}=$ 164 velocity pressure calculated at mean roof height $h$.

165 Wind pressure for the main wind force resisting system (MWFRS) is then calculated as:

166

$$
p=q G C_{p}-q_{i}\left(\mathrm{GC}_{p i}\right) \quad\left(\mathrm{lb} / \mathrm{ft}^{2}\right)\left(\mathrm{N} / \mathrm{m}^{2}\right)
$$


167 where, $q$ and $q_{i}$ are velocity pressure calculated at height $z$ or $h, G=$ gust-effect factor, $C_{p}=$ 168 external pressure coefficient, and $G C_{p i}=$ internal pressure coefficient.

169 For components and claddings $(\mathrm{C} \& \mathrm{C})$ wind pressure is determined as:

$$
p=q_{h}\left[\left(G C_{p}\right)-\left(G C_{p i}\right)\right] \quad\left(\mathrm{lb} / \mathrm{ft}^{2}\right)\left(\mathrm{N} / \mathrm{m}^{2}\right)
$$

171 where, $q_{h}=$ velocity pressure evaluated at mean roof height $h,\left(G C_{p}\right)=$ external pressure 172 coefficients, and $\left(G C_{p i}\right)=$ internal pressure coefficient.

173 The winds from a tornado extend 9,000 to 15,000 meters $(30,000$ to 50,000 feet) above the 174 ground and are a turbulent phenomenon. In general, there are many key differences between 175 tornadoes and straight-line wind. In this study, the ASCE 7-10 [18] methodology for straight-line 176 wind loads with certain modifications was applied to obtain the tornado-induced forces.

177 The first modification is with regard to the directionality factor, $K_{d}$. Justification for using the 178 directionality factor is mentioned in the ASCE 7-10 commentary [18] as the following: "This 179 factor accounts for two effects: (1) The reduced probability of maximum winds coming from any 180 given direction and (2) the reduced probability of the maximum pressure coefficient occurring 181 for any given wind direction." Indeed, these effects consider circumstances in which it is 182 probable that the strongest winds come from a non-critical direction. All of these considerations 183 deal with straight-line winds but the maximum wind speed can occur from any direction in 184 tornadoes, which may exert a maximum pressure coefficient on buildings from any direction [30, 185 34]. Thus, the directionality factor is conservatively neglected in the tornado-induced load 186 calculation and is set equal to 1.0 in determination of tornadic loads in the present study.

187 The second consideration for wind loading is that different exposures in ASCE 7-10 [18] result 188 in a different coefficient for straight-line winds. Several studies have been completed regarding 189 the effects of ground surface roughness in tornadoes [35-40]. Sabareesh et al. [39] showed that 190 with introduction of roughness the internal pressures decrease in magnitude irrespective of swirl 191 ratio, external pressures decrease in magnitude compared to internal pressures, and the net local 192 roof wind force increases in magnitude. However, in this study, regardless of the ground surface 193 roughness and the fetch length of the surrounding terrain, the analysis is based on Exposure C. 
194 Moreover, there is an ongoing debate related to modification of pressure coefficients. Several 195 studies have shown that tornadoes result in greater pressure on buildings than straight-line winds 196 for the same reference wind speed [12-15, 38, 41]. However, there is no consensus in the 197 intensity of pressure that tornadoes can apply on building surfaces since tornado loading still 198 possesses significant uncertainty primarily related to researchers understanding of the 199 phenomena. Therefore, additional parameters are defined in this study to modify pressure 200 coefficients. The modification of the pressure coefficient is divided into two parameters to 201 separate internal and external pressure coefficients which can be different in ASCE 7. The first 202 parameter is defined herein to modify the external pressure coefficients, $T_{e}$, a tornado external 203 pressure adjustment which is similar to past studies; and the second coefficient is $T_{i}$, a tornado 204 internal pressure adjustment, which needs further investigation and is set to 0.0 or 1.0 in this 205 study.

206 The modifications described above are applied to the method outlined in the wind provisions of 207 ASCE 7-10 [18] to assess wind loads from tornadoes in this study. Moreover, local topographic 208 effect was neglected, i.e. $K_{z t}$ is assumed to be 1.0, and all the analyses either for the main wind 209 force resisting system (MWFRS) or for components and claddings (C\&C) were determined 210 based on velocity pressure calculated at mean roof height h, i.e. $q_{h}$. Since the near-surface wind 211 flow in tornadoes is turbulent and has not been adequately studied, this assumption is felt to be 212 rational. Thus, the tornado-induced wind load is calculated by following equations:

$$
q_{h}=0.613 K_{h} K_{z t} V^{2} \quad\left(\mathrm{~N} / \mathrm{m}^{2}\right) ; V \text { in } \mathrm{m} / \mathrm{s}
$$

215 where, $K_{h}=$ velocity pressure exposure coefficient at mean roof height $h, K_{z t}=$ topographic 216 factor, $V=3$-sec gust wind speed, and $q_{h}=$ velocity pressure calculated at mean roof height $h$.

$217 p=q_{h}\left[T_{e}\left(G C_{p}\right)-T_{i}\left(G C_{p i}\right)\right] \quad\left(\mathrm{lb} / \mathrm{ft}^{2}\right)\left(\mathrm{N} / \mathrm{m}^{2}\right)$

218 where, $q_{h}=$ velocity pressure evaluated at mean roof height $h, G=$ gust-effect factor, $C_{p}=$ 219 external pressure coefficient, $\left(G C_{p i}\right)=$ internal pressure coefficient, $T_{e}=$ tornado external 220 pressure adjustment, and $T_{i}=$ tornado internal pressure adjustment. 
221 In order to calculate tornado-induced wind loads by using Equation 7, two alternative approaches

222 were considered in this study - namely approach A and B, which are as follows:

223 Approach A: Using ASCE 7-10 pressure coefficients along with tornado pressure adjustments 224 derived based on the study done by Haan et al. [14].

225 Haan et al. [14] studied tornado-induced wind loads in a laboratory-simulated tornado on a 1:100 226 scale one-story gable roof building model with a $91 \mathrm{~mm}$ by $91 \mathrm{~mm}$ (3.6 in. by $3.6 \mathrm{in}$.) plan, an 227 eave height of $36 \mathrm{~mm}$ (1.4 in), and roof angle of $35^{\circ}$. They compared the measured pressures 228 with the ASCE-7 standard, and found that external pressure coefficients appeared to be greater 229 than those prescribed by ASCE 7-05 [18] for straight-line winds over open terrain. Based on 230 their study, the uplift pressure coefficients for the MWFRS and for C\&C exceeded those from 231 the ASCE 7-05 [18] wind provisions by a factor of 1.8-3.2 and 1.4-2.4, respectively. They 232 assumed a fully sealed building in their study, which negated the effect of internal pressure 233 change on mitigating the static pressure drop caused by the tornado vortex. However, there exist 234 openings and some level of leakage in typical buildings which could significantly decrease the 235 effect of static pressure drop [41]. Therefore, using these coefficients as $T_{e}$ in Equation 7 requires 236 that $T_{i}$ be set equal to zero since the internal pressure has already been considered inherently in 237 coefficients identified by Haan et al. [14]. It is worth mentioning that although openings reduce 238 the effect of the static pressure drop, at the same time they may cause notable internal pressure 239 by letting wind flows into building $[16,20]$. A similar observation was made for lateral pressure 240 coefficients, and revealed that the pressure coefficients ranged from 1.0 to 1.5 times larger than 241 those coefficients in ASCE 7-05 [18] for MWFRS and 1.2 to 1.5 times larger for C\&C. Using the 242 values obtained for adjusting the lateral pressure coefficients for C\&C (i.e. $T_{e}$ ranges between 1.2 243 and 1.5) in Equation 7, $T_{i}$ should be set equal to zero for the same reason explained above for the 244 MWFRS and C\&C. However, lateral pressure coefficients for MWFRS were calculated by 245 integrating the pressures over the model surface, which canceled out the static pressures effect 246 (internal pressure and pressure drop) only in this case [14]. Therefore, using this $T_{e}$ value for 247 lateral pressure coefficients for MWFRS in Equation 7 should be done by setting $T_{i}$ equal to 1.0.

248 Approach B: Using ASCE 7-16 pressure coefficients along with both $T_{e}$ and $T_{i}$ equal to 1.0. 
249 The ASCE 7-16 coefficients for roof pressures are notably larger than the ASCE 7-10 based on 250 recent wind tunnel test results [42], and are believed to be derived from the best pressure 251 measurements generated to date. Moreover, as discussed earlier, internal pressure is neglected in 252 approach A (except for estimating lateral pressures on MWFRS). However, in some cases, 253 including internal pressure and using tornado pressure adjustments equal to 1.0 in Equation 7 254 may result in a higher load than when using approach A. In this regard, the alternative approach $255 \mathrm{~B}$ is defined by setting the tornado pressure adjustments (i.e. $T_{e}$ and $T_{i}$ ) equal to 1.0 and the 256 ASCE 7-16 pressure coefficients [42] were used representing the best knowledge in pressure 257 coefficients currently available for straight-line winds.

258 The differences between the approaches A and B for calculating tornado-induced load by using 259 Equation 7 are highlighted in Table 1.

260 Table 1. Difference between Approaches A and B for Calculating Tornado-induced Load

\begin{tabular}{|c|c|c|c|c|c|}
\hline Paramete & s Description & & & Approach A & Approach B \\
\hline \multirow{8}{*}{ Tornado Pressure Adjustment } & \multirow{4}{*}{ Uplift Pressure } & \multirow{2}{*}{ MWFRS } & $\mathrm{T}_{\mathrm{e}}$ & $1.8-3.2$ & \multirow{8}{*}{1.0} \\
\hline & & & $\mathrm{T}_{\mathrm{i}}$ & 0.0 & \\
\hline & & \multirow{2}{*}{$\mathrm{C} \& \mathrm{C}$} & $\mathrm{T}_{\mathrm{e}}$ & $1.4-2.4$ & \\
\hline & & & $\mathrm{T}_{\mathrm{i}}$ & 0.0 & \\
\hline & \multirow{4}{*}{ Lateral Pressure } & \multirow{2}{*}{ MWFRS } & $\mathrm{T}_{\mathrm{e}}$ & $1.0-1.5$ & \\
\hline & & & $\mathrm{T}_{\mathrm{i}}$ & 1.0 & \\
\hline & & \multirow{2}{*}{$\mathrm{C} \& \mathrm{C}$} & $\mathrm{T}_{\mathrm{e}}$ & $1.2-2.0$ & \\
\hline & & & $\mathrm{T}_{\mathrm{i}}$ & 0.0 & \\
\hline External Pressure Coefficients & $\mathrm{GC}_{\mathrm{p}}$ & & & ASCE 7-10 & ASCE 7-16 \\
\hline
\end{tabular}

262 Statistics for wind load parameters are summarized in Table 2 and Table 3. Since the school 263 building studied here has a flat roof, the nominal values for $\mathrm{GC}_{\mathrm{p}}$ for roof cover are based on the 264 values in ASCE 7 for gable roofs with $\theta \leq 7^{\circ}$. As mentioned before, the topographic factor, $K_{z}$, 265 is deterministic and set equal to 1.0 in this study. The ASCE 7-16 parameters [42] used in this 266 study are same as those of the ASCE 7-10 [18] except the external pressure coefficients for roof 267 C\&C which are tabulated in Table 4. 
Table 2. Wind Load Statistics

\begin{tabular}{|c|c|c|c|c|c|c|c|}
\hline Parameters & \multicolumn{2}{|c|}{ Descriptions } & Nominal & Mean & $\mathrm{COV}$ & Distribution & References \\
\hline \multirow{5}{*}{$\mathbf{K}_{\mathbf{z}}$} & \multicolumn{2}{|c|}{$0-4.57 \mathrm{~m}(0-15 \mathrm{ft})$} & 0.85 & 0.82 & & & \\
\hline & \multicolumn{2}{|c|}{$6.10 \mathrm{~m}(20 \mathrm{ft})$} & 0.90 & 0.84 & & & \\
\hline & \multicolumn{2}{|c|}{$7.62 \mathrm{~m} \mathrm{(25 \textrm {ft } )}$} & 0.94 & 0.88 & 0.14 & Normal & {$[23,43]$} \\
\hline & \multicolumn{2}{|c|}{$9.14 \mathrm{~m}(30 \mathrm{ft})$} & 0.98 & 0.94 & & & \\
\hline & \multicolumn{2}{|c|}{ 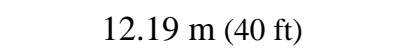 } & 1.04 & 1.00 & & & \\
\hline G & - & & - & 0.82 & 0.10 & Normal & {$[44]$} \\
\hline \multirow{4}{*}{$\mathbf{T}_{\mathbf{e}}$} & \multirow{2}{*}{ Uplift Pressure } & MWFRS & $1.8-3.2$ & \multirow{4}{*}{-} & \multirow{4}{*}{-} & \multirow{4}{*}{ Uniform } & \multirow{4}{*}[14,23]{} \\
\hline & & $\mathrm{C} \& \mathrm{C}$ & $1.4-2.4$ & & & & \\
\hline & \multirow{2}{*}{ Lateral Pressure } & MWFRS & $1.0-1.5$ & & & & \\
\hline & & $\mathrm{C} \& \mathrm{C}$ & $1.2-2.0$ & & & & \\
\hline
\end{tabular}

270 Table 3. Wind Load Statistics- Pressure Coefficients

\begin{tabular}{llccccc}
\hline Parameters & Descriptions & Nominal & Mean & COV & Distribution & References \\
\hline \multirow{3}{*}{$\mathbf{G C}_{\mathbf{p i}}$} & Enclosed Buildings & 0.18 & 0.15 & & & \\
& Partially Enclosed & 0.55 & 0.46 & 0.33 & Normal & {$[23,43]$} \\
& Buildings & 0.80 & 0.69 & 0.15 & Normal & {$[44]$} \\
\hline \multirow{2}{*}{$\mathbf{C}_{\mathbf{p}}$} & Wall & -0.90 & -0.81 & & & \\
\hline \multirow{3}{*}{} & Roof & 1.50 & 1.43 & 0.18 & & \\
& Parapet & -0.86 & -0.81 & 0.12 & & \\
$\mathbf{G C}_{\mathbf{p}}$ & Door & -0.81 & -0.77 & 0.12 & & \\
& Window & -1.00 & -0.95 & 0.12 & Normal & {$[44]$} \\
& Roof Cover- Zone 1 & -1.80 & -1.71 & 0.12 & & \\
& Roof Cover- Zone 2 & -2.80 & -2.66 & 0.12 & & \\
\hline
\end{tabular}

272 Table 4. External pressure coefficients for roof C\&C in ASCE 7-16

\begin{tabular}{llccccc}
\hline Parameters & Descriptions & Nominal & Mean & COV & Distribution & References \\
\hline \multirow{3}{*}{ GC $_{\mathbf{p}}$} & Roof Cover- Zone 1' & -0.90 & -0.86 & 0.12 & & COV and Mean: \\
& Roof Cover- Zone 1 & -1.70 & -1.62 & 0.12 & Normal & [44] \\
& Roof Cover- Zone 2 & -2.30 & -2.19 & 0.12 & & Nominal: \\
\hline
\end{tabular}




\subsection{Resistance Modeling}

275 Recall that many of the school buildings described earlier that failed in tornadoes were 276 constructed using masonry walls, which is a common building type for schools around the U.S.

277 For edge-supported (by roof, floor, and adjacent walls, etc.) unreinforced masonry walls under 278 uniform lateral pressure loading, the major failure mechanism is associated with cracking due to 279 flexural tensile stress [9]. Therefore, tensile strength is the most important failure metric in 280 unreinforced masonry design, which is a function of several factors including tension direction, 281 such as tension parallel to or perpendicular to the bed joint; type of units, i.e. solid units or 282 hollow units; the unit grouting condition, i.e. ungrouted, partially grouted, or fully grouted; and 283 the mortar type, such as Portland-Cement Lime mortar (PCL) or Masonry Cement (MC) mortar, 284 which can be type M, S, or N mortar. The out-of-plane modulus of rupture values in the strength 285 provisions of the Masonry Standards Joint Committee (MSJC) code [45] are approximately 1.9 286 times the allowable stress design values. Since no source data is available for partially grouted 287 masonry, its values are determined on the basis of linear interpolation between fully grouted 288 hollow units and ungrouted hollow units based on amount (percentage) of grouting [45]. In this 289 study, 25 percent of grouting was assumed as the definition of partially grouted masonry which 290 would be consistent with grouting of cells at 1.53 to 1.83 meter (5 to 6 feet) on-center for 291 reinforcement. Two types of concrete masonry units (12" CMU for gyms and auditoriums, and 292 8" CMU for the rest of the building) and five types of masonry material are considered in this 293 study.

294 A summary of the flexural tension values is given in Table 5; all the values are related to tension 295 normal to bed joints in hollow units. The table gives the sample size, mean, and coefficient of 296 variation of each masonry material type. Furthermore, the current allowable flexural tension 297 stress and modulus of rupture in the MSJC code [45], and the ratio of the mean flexural tension 298 stress to allowable stress is highlighted in the aforementioned table. All flexural tension values 299 given in Table 5 are based on net cross-sectional properties [46], and normal distributions were 300 assigned for all of these materials. 
301 Table 5. Statistics of Masonry Flexural Tension- Normal to bed joints, Hollow units [46].

\begin{tabular}{|c|c|c|c|c|c|c|c|}
\hline Type & $\begin{array}{l}\text { Masonry and } \\
\text { Mortar Types }\end{array}$ & $\begin{array}{l}\text { Sample } \\
\text { Size }\end{array}$ & Mean & $\mathrm{COV}$ & $\begin{array}{l}\text { Modulus of } \\
\text { Rupture in } \\
\text { MSJC Code }\end{array}$ & $\begin{array}{c}\text { Allowable } \\
\text { Stress in MSJC } \\
\text { Code }\end{array}$ & $\begin{array}{c}\text { Ratio of Mean } \\
\text { to Allowable } \\
\text { Stress }\end{array}$ \\
\hline M1 & $\begin{array}{l}\text { Fully Grouted, } \\
\text { M/S, PCL }\end{array}$ & 6 & $\begin{array}{c}2.0 \mathrm{MPa} \\
(289.6 \mathrm{psi})\end{array}$ & 0.11 & $\begin{array}{l}1.12 \mathrm{MPa} \\
(163 \mathrm{psi})\end{array}$ & $\begin{array}{l}0.59 \mathrm{MPa} \\
(86 \mathrm{psi})\end{array}$ & 3.37 \\
\hline M2 & $\begin{array}{l}\text { Partially } \\
\text { Grouted, M/S, } \\
\text { PCL }\end{array}$ & $-*$ & $\begin{array}{l}1.47 \mathrm{MPa} \\
(213.0 \mathrm{psi})\end{array}$ & 0.31 & $\begin{array}{l}0.61 \mathrm{MPa} \\
(88 \mathrm{psi})\end{array}$ & $\begin{array}{l}0.32 \mathrm{MPa} \\
\quad(46 \mathrm{psi})\end{array}$ & 4.63 \\
\hline M3 & $\begin{array}{l}\text { Ungrouted, } \\
\text { M/S, PCL }\end{array}$ & 80 & $\begin{array}{l}1.29 \mathrm{MPa} \\
(186.5 \mathrm{psi})\end{array}$ & 0.48 & $\begin{array}{l}0.43 \mathrm{MPa} \\
\quad(63 \mathrm{psi})\end{array}$ & $\begin{array}{l}0.23 \mathrm{MPa} \\
(33 \mathrm{psi})\end{array}$ & 5.65 \\
\hline M4 & $\begin{array}{l}\text { Ungrouted, N, } \\
\text { PCL }\end{array}$ & 61 & $\begin{array}{l}0.69 \mathrm{MPa} \\
(100.5 \mathrm{psi})\end{array}$ & 0.45 & $\begin{array}{l}0.33 \mathrm{MPa} \\
(48 \mathrm{psi})\end{array}$ & $\begin{array}{l}0.17 \mathrm{MPa} \\
(25 \mathrm{psi})\end{array}$ & 4.02 \\
\hline M5 & $\begin{array}{l}\text { Ungrouted, N, } \\
\text { MC }\end{array}$ & 17 & $\begin{array}{c}0.36 \mathrm{MPa} \\
(52.7 \mathrm{psi})\end{array}$ & 0.45 & $\begin{array}{c}0.16 \mathrm{MPa} \\
(23 \mathrm{psi})\end{array}$ & $\begin{array}{c}0.08 \mathrm{MPa} \\
\quad(12 \mathrm{psi})\end{array}$ & 4.39 \\
\hline
\end{tabular}

302

303

314 The statistics for negative moment resistance and material properties of precast concrete beams 315 are provided in Table 6. The statistics for negative moment resistance of beams are calculated 316 based on material properties and conventional procedures in precast concrete structural analysis.

317 The section properties and strands pattern of each beam were determined using a PCI (1971) 318 design manual [47]. The old Xenia senior high school, which was destroyed in the 1974 tornado, 319 had been built in 1957, but the archetype herein was designed to be representative of a 1970's 320 school. 
321 Table 6. Summary of Statistics for Negative Moment Resistance and Material Properties of Roof 322 Beams

\begin{tabular}{|c|c|c|c|c|c|}
\hline \multicolumn{2}{|c|}{ Parameters Description } & Mean & $\mathrm{COV}$ & Distribution & References \\
\hline \multicolumn{2}{|c|}{$\mathbf{f}_{\mathbf{c}}$ (Concrete 28-day cylinder strengths) } & $\begin{array}{l}45.85 \mathrm{MPa} \\
(6.65 \mathrm{ksi})\end{array}$ & 0.130 & \multirow{4}{*}{ Normal } & {$[48]$} \\
\hline \multicolumn{2}{|c|}{$\mathbf{f}_{\mathbf{y}}$ (Yield strength of reinforcement bars) } & $\begin{array}{l}475.74 \mathrm{MPa} \\
(69 \mathrm{ksi})\end{array}$ & 0.073 & & [49] \\
\hline \multicolumn{2}{|c|}{$\mathbf{E}_{\mathbf{p s}}$ (Modulus of Elasticity of Grade 270 Strands) } & $\begin{array}{l}195928 \mathrm{MPa} \\
(28417 \mathrm{ksi})\end{array}$ & 0.034 & & {$[50]$} \\
\hline \multicolumn{2}{|c|}{$\mathbf{f}_{\mathbf{p u}}$ (Ultimate Strength of Grade 270 Strands) } & $\begin{array}{l}1992.6 \mathrm{MPa} \\
(289 \mathrm{ksi})\end{array}$ & 0.087 & & {$[50]$} \\
\hline \multirow{4}{*}{$\begin{array}{l}\text { Negative } \\
\text { Moment } \\
\text { Resistance }\end{array}$} & 4HC8+2 With Strand Code 58-S & $\begin{array}{l}19.66 \mathrm{kN} . \mathrm{m} \\
(174 \text { kip.in })\end{array}$ & 0.086 & \multirow{4}{*}{ Normal } & \multirow{4}{*}{$\begin{array}{c}\text { Based on } \\
\text { Calculation and PCI } \\
\text { (1971) [47] }\end{array}$} \\
\hline & 8ST36+2 With Strand Code 128-D1 & $\begin{array}{l}221.56 \mathrm{kN} . \mathrm{m} \\
\text { (1961 kip.in) }\end{array}$ & 0.076 & & \\
\hline & 10ST48+2 With Strand Code 148-D1 & $\begin{array}{l}275.23 \text { kN.m } \\
\text { (2436 kip.in) }\end{array}$ & 0.080 & & \\
\hline & 10ST48+2 With Strand Code 188-D1 & $\begin{array}{l}265.06 \text { kN.m } \\
\text { (2346 kip.in) }\end{array}$ & 0.095 & & \\
\hline
\end{tabular}

324 Moreover, the connections between the precast concrete decks and wall are not usually designed 325 for uplift loads. Therefore, because the deck dead load itself is often inadequate to resist the 326 tornado uplift, bolt break out can be another roof failure mode in this case. Bolt break out 327 statistics are given in Table 7.

328 Table 7. Roof-to-Wall Connections Statistics

\begin{tabular}{lcccc}
\hline Description & Mean & COV & Distribution & References \\
\hline Bolt \#5; 8" CMU; Fully Grouted & $49.73 \mathrm{kN}$ & 0.10 & & \\
& $(11.18 \mathrm{kip})$ & & & \\
Bolt \#5; 8" CMU; Partially Grouted & $32.65 \mathrm{kN}$ & 0.12 & & \\
& $(7.34 \mathrm{kip})$ & & Normal & {$[51]$} \\
Bolt \#5; 12" CMU; Fully Grouted & $51.38 \mathrm{kN}$ & 0.15 & & \\
& $(11.55 \mathrm{kip})$ & & & \\
Bolt \#5; 12" CMU; Partially Grouted & $40.52 \mathrm{kN}$ & 0.10 & & \\
& $(9.11 \mathrm{kip})$ & & & \\
\hline
\end{tabular}

330 Roof covering damage (including rooftop equipment) is the most common type of wind damage. 331 Built-up roof (BUR) covers and single-ply membrane (SPM) covers can be used as a roof cover 
332 system. BUR covers are comprised of multiple plies of roofing felts adhered to each other and to 333 the insulation substrate with a full mop of hot asphalt, coal tar or cold adhesive [9]. Failure of the 334 perimeter flashing is usually the first wind-induced failure for BUR covers, which then expedites 335 peeling for the roof cover membrane at the newly exposed edge; the peeling failure can continue 336 and result in extensive roof cover damage. Bubbling is another roof cover failure, where the roof 337 cover is separated from the substrate by high wind uplift pressures. A bubbled part of the roof 338 membrane may become breached by impact from flying debris or by tearing at the perimeter of 339 the bubble, or it may expand to an area where the roof cover is torn and therefore that bubbled 340 section can also tear. Moreover, since BUR covers are often surfaced with gravel or slag, the 341 loose aggregate of the built-up roof can blow off and cause damage to windows in nearby 342 houses. Window and door damage is among the most common wind damage. The importance of 343 building envelope damage cannot be understated because of water intrusion into buildings at 344 envelope breaches. The resistance statistics for the BUR roof cover, windows, and doors are 345 shown in Table 8.

346 Table 8. Resistance Statistics for Roof Cover, Window, and Door

\begin{tabular}{|c|c|c|c|c|c|}
\hline \multicolumn{2}{|c|}{ Component } & \multirow{2}{*}{$\begin{array}{c}\text { Mean } \\
328.36 \mathrm{~N} / \mathrm{m} \\
(22.5 \mathrm{plf})\end{array}$} & \multirow{2}{*}{$\begin{array}{c}\text { COV } \\
0.30\end{array}$} & \multirow[t]{2}{*}{ Distribution } & \multirow{2}{*}{ References } \\
\hline \multirow{3}{*}{ BUR Roof Cover } & Flashing Resistance & & & & \\
\hline & Peeling Resistance & $\begin{array}{c}2.39 \mathrm{kPa} \\
(50 \mathrm{psf})\end{array}$ & 0.15 & \multirow{4}{*}{ Normal } & \multirow{4}{*}{ [9] } \\
\hline & Bubbling Resistance & $\begin{array}{l}7.18 \mathrm{kPa} \\
(150 \mathrm{psf})\end{array}$ & 0.15 & & \\
\hline \multicolumn{2}{|c|}{ Windows Resistance } & $\begin{array}{l}1.92 \mathrm{kPa} \\
(40 \mathrm{psf})\end{array}$ & 0.20 & & \\
\hline \multicolumn{2}{|l|}{ Doors Resistance } & $\begin{array}{c}2.39 \mathrm{kPa} \\
(50 \mathrm{psf})\end{array}$ & 0.20 & & \\
\hline
\end{tabular}

\section{7}

348 Dead loads have a beneficial effect in wind-induced fragility analysis since they resist uplift 349 loading and must therefore be included in the analysis. Dead load statistics for precast concrete 350 roofs and concrete masonry units are provided in Table 9. 


\begin{tabular}{|c|c|c|c|c|}
\hline Element Type & Mean & COV & Distribution & Sources \\
\hline Hollow-Core Beam (4'HC8') & $\begin{array}{c}4.73 \mathrm{kN} / \mathrm{m} \\
(324 \mathrm{plf})\end{array}$ & \multirow{3}{*}{0.1} & \multirow{3}{*}{ Normal } & \multirow{3}{*}{$\begin{array}{c}\text { COV and Distribution Type: } \\
\text { [32]; } \\
\text { Mean Values: } \\
{[47]}\end{array}$} \\
\hline Single-Tee Beam (8'ST36'”) & $\begin{array}{c}11.59 \mathrm{kN} / \mathrm{m} \\
(794 \mathrm{plf})\end{array}$ & & & \\
\hline Single-Tee Beam (10'ST48') & $\begin{array}{c}15.54 \mathrm{kN} / \mathrm{m} \\
(1065 \mathrm{plf})\end{array}$ & & & \\
\hline CMU 8' & $\begin{array}{c}2.30 \mathrm{kPa} \\
(48 \mathrm{psf})\end{array}$ & \multirow[b]{2}{*}{0.1} & \multirow[b]{2}{*}{ Normal } & \multirow{2}{*}{$\begin{array}{c}\text { COV and Distribution Type } \\
{[32]}\end{array}$} \\
\hline CMU 12' & $\begin{array}{c}3.54 \mathrm{kPa} \\
(74 \mathrm{psf})\end{array}$ & & & \\
\hline
\end{tabular}

\subsection{Damage States}

354 In this study, damage states for school buildings are defined based on the approach used by Vann 355 and McDonald [52]. The damage states used for school buildings are defined in Table 10 and are 356 governed by the performance of the building envelope, roof structure, and walls. Damage is 357 classified into five states, varying between 0 and 4 for consistency with HAZUS-MH-MR4 [9]:

358 Damage State 0 (No Damage): Little or no visible damage from the outside; No broken windows 359 or doors; Minimal loss of roof cover, with no or very limited water penetration.

360 Damage State 1 (Minor Damage): Maximum of one or two broken windows or doors; Moderate 361 roof cover loss that can be covered with a tarp to prevent additional water entering the building ${ }^{1}$;

362 Marks or dents on walls requiring painting or patching for repair.

363 Damage State 2 (Moderate Damage): Still capable of being occupied; Major roof cover damage;

364 Moderate window breakage; Some resulting damage to interior of the building from water.

365 Damage State 3 (Severe Damage): Not able to be occupied, but repairable; Major roof cover 366 loss; Major loss of windows and doors; Extensive damage to interior from water; Non-load367 bearing wall failure.

\footnotetext{
${ }^{1}$ It should be noted that unlike hurricanes, not all tornadoes are accompanied by rainfall. One example is the 2011 EF4 Tuscaloosa tornado that had very little rainfall associated with it until later in the day from a second supercell that spawned tornadoes in different locations.
} 
Damage State 4 (Destruction): Not able to be occupied and not repairable; Roof system failure;

369 Load-bearing wall failure.

370 If any of the shaded damage indicators in a given row of Table 10 occur, the school building is 371 considered to be in that damage state. For example, for a school to be considered to have 372 sustained damage state 4 (Destruction), the building must have sustained either roof structural 373 failure or load-bearing wall failure. It is worth mentioning that in damage state 4 the first four 374 damage indicators will typically occur, which means damage state 4 depends only on roof 375 structural failure and load-bearing wall failure.

376 Table 10. Damage States for School Building

\begin{tabular}{|c|c|c|c|c|c|c|}
\hline $\begin{array}{c}\text { Damage } \\
\text { State }\end{array}$ & $\begin{array}{l}\text { Roof Cover } \\
\text { Failure }\end{array}$ & $\begin{array}{l}\text { Window/Door } \\
\text { Failures }\end{array}$ & $\begin{array}{l}\text { Parapet } \\
\text { Failure }\end{array}$ & $\begin{array}{l}\text { Non-load- } \\
\text { bearing Wall } \\
\text { Failure }\end{array}$ & $\begin{array}{c}\text { Roof } \\
\text { Structural } \\
\text { Failure }\end{array}$ & $\begin{array}{l}\text { Load-bearing } \\
\text { Wall Failure }\end{array}$ \\
\hline $\mathbf{0}$ & $\leq 2 \%$ & No & No & No & No & No \\
\hline 1 & $\begin{array}{c}>2 \% \\
\text { and } \\
\leq 15 \%\end{array}$ & 1 or 2 & No & No & No & No \\
\hline 2 & $\begin{array}{c}>15 \% \\
\text { and } \\
\leq 50 \%\end{array}$ & $\begin{array}{c}>1 \text { or } 2 \\
\text { and } \\
\leq 25 \%\end{array}$ & No & No & No & No \\
\hline 3 & $>50 \%$ & $>25 \%$ & Yes & Yes & No & No \\
\hline 4 & $\begin{array}{c}\text { Typically } \\
>50 \%\end{array}$ & $\begin{array}{c}\text { Typically } \\
>25 \%\end{array}$ & $\begin{array}{c}\text { Typically } \\
\text { Yes }\end{array}$ & Typically Yes & Yes & Yes \\
\hline
\end{tabular}

* Each damage state is defined as occurrence of any of the shaded damage indicators in a given row.

\section{Tornado Hazard Model}

379 Five types of masonry construction (with properties summarized in Table 5) were investigated in 380 this study in order to provide fragility functions applicable to different locations throughout the 381 United States. Therefore, five cities across the US that each have a different tornado hazard, were 382 selected. Norman, Oklahoma as a part of Tornado Alley was selected to be representative of a 383 region of high tornado activity. Xenia, Ohio and Omaha, Nebraska were selected as moderately 384 tornado-prone regions. Tampa, Florida and Phoenix, Arizona were selected as regions with 385 relatively weak and very low risk of tornado, respectively. The tornado hazard curves for these 386 locations are shown in Figure 2 in the form of complementary cumulative distribution functions 387 (CCDF). In order to develop each hazard curve, the mean annual probability of occurrence of 
each EF scale was obtained from the tornado hazard maps created by Standohar-Alfano and van

389 de Lindt [53]. Table 11 provides the mean annual occurrence probability of each EF category for 390 these five U.S. cities.

391 Table 11. Mean Annual Probability of Occurrence of each EF Category

\begin{tabular}{|c|c|c|c|c|c|c|}
\hline EF Category & EFO & EF1 & EF2 & EF3 & EF4 & EF5 \\
\hline $\begin{array}{r}\text { Speed Range- } \begin{array}{r}\mathbf{m} / \mathbf{s} \\
(\mathbf{m p h})\end{array}\end{array}$ & $\begin{array}{l}29 \leq \mathrm{v}<38 \\
(65 \leq \mathrm{v}<86)\end{array}$ & $\begin{array}{c}38 \leq \mathrm{v}<50 \\
(86 \leq \mathrm{v}<111)\end{array}$ & $\begin{array}{c}50 \leq \mathrm{v}<61 \\
(111 \leq \mathrm{v}<136)\end{array}$ & $\begin{array}{c}61 \leq \mathrm{v}<74 \\
(136 \leq \mathrm{v}<166)\end{array}$ & $\begin{array}{c}74 \leq \mathrm{v} \leq 90 \\
(166 \leq \mathrm{v} \leq 200)\end{array}$ & $\begin{array}{l}90<v \\
(200<v)\end{array}$ \\
\hline Norman, OK & 3.69E-04 & $2.18 \mathrm{E}-04$ & $7.00 \mathrm{E}-05$ & $1.20 \mathrm{E}-05$ & $1.05 \mathrm{E}-06$ & $1.43 \mathrm{E}-08$ \\
\hline Xenia, OH & $8.05 \mathrm{E}-05$ & $3.70 \mathrm{E}-05$ & 8.93E-06 & $1.21 \mathrm{E}-06$ & $9.38 \mathrm{E}-08$ & $1.65 \mathrm{E}-09$ \\
\hline Omaha, NE & $1.20 \mathrm{E}-04$ & 4.95E-05 & 8.55E-06 & $9.04 \mathrm{E}-07$ & $1.28 \mathrm{E}-08$ & $1.26 \mathrm{E}-10$ \\
\hline Tampa, FL & $4.52 \mathrm{E}-05$ & 8.43E-06 & $2.81 \mathrm{E}-07$ & 2.28E-09 & $1.83 \mathrm{E}-14^{*}$ & $1.56 \mathrm{E}-19^{*}$ \\
\hline Phoenix, AZ & $3.02 \mathrm{E}-06$ & $7.24 \mathrm{E}-07$ & 4.87E-09 & $1.83 \mathrm{E}-11$ & $1.09 \mathrm{E}-15^{*}$ & $7.50 \mathrm{E}-22^{*}$ \\
\hline
\end{tabular}

* Mathematically computed; but may be an unrealistic extrapolation.

393 Based on the speed range of each EF category mentioned in Table 11, the probability of 394 exceeding the lower limit of wind speed related to each EF scale can be evaluated by summation 395 of the occurrence probability of each EF scale above that upper EF rate. For example, since an 396 EF4 tornado is defined as a tornado with wind speeds between $74 \mathrm{~m} / \mathrm{s}(166 \mathrm{mph})$ and $90 \mathrm{~m} / \mathrm{s}$ 397 (200 $\mathrm{mph}$ ), and an EF5 tornado has speeds exceeding $90 \mathrm{~m} / \mathrm{s}(200 \mathrm{mph})$; then, the probability 398 that a tornado exceeding $74 \mathrm{~m} / \mathrm{s}(166 \mathrm{mph})$ would be, for example, 1.07E-06 for Norman (i.e. 399 1.43E-08 plus 1.05E-06). Therefore, the mean annual probability of exceeding the lower limit of 400 wind speed related to each EF scale was calculated and is presented in Table 12.

401 Table 12. Mean Annual Probability of Exceeding the lower limit of wind speed related to each 402 EF Category

\begin{tabular}{lcccccc}
\hline EF Category & $\begin{array}{c}\text { EF0 and } \\
\text { above }\end{array}$ & $\begin{array}{c}\text { EF1 and } \\
\text { above }\end{array}$ & $\begin{array}{c}\text { EF2 and } \\
\text { above }\end{array}$ & $\begin{array}{c}\text { EF3 and } \\
\text { above }\end{array}$ & $\begin{array}{c}\text { EF4 and } \\
\text { above }\end{array}$ & EF5 \\
\hline Speed Range- $\mathbf{~ m / s}$ & $\begin{array}{c}29 \leq \mathrm{v}<38 \\
(\mathbf{m p h})\end{array}$ & $\begin{array}{c}38 \leq \mathrm{v}<50 \\
(65 \leq \mathrm{v}<86)\end{array}$ & $\begin{array}{c}50 \leq \mathrm{v}<61 \\
(86 \leq \mathrm{v}<111)\end{array}$ & $\begin{array}{c}61 \leq \mathrm{v}<74 \\
(111 \leq \mathrm{v}<136)\end{array}$ & $\begin{array}{c}74 \leq \mathrm{v} \leq 90 \\
(136 \leq \mathrm{v}<166)\end{array}$ & $\begin{array}{c}(166 \leq \mathrm{v} \leq 200) \\
(200<\mathrm{v})\end{array}$ \\
\hline Norman, OK & $6.69 \mathrm{E}-04$ & $3.01 \mathrm{E}-04$ & $8.31 \mathrm{E}-05$ & $1.31 \mathrm{E}-05$ & $1.07 \mathrm{E}-06$ & $1.43 \mathrm{E}-08$ \\
Xenia, OH & $1.28 \mathrm{E}-04$ & $4.72 \mathrm{E}-05$ & $1.02 \mathrm{E}-05$ & $1.30 \mathrm{E}-06$ & $9.55 \mathrm{E}-08$ & $1.65 \mathrm{E}-09$ \\
Omaha, NE & $1.79 \mathrm{E}-04$ & $5.90 \mathrm{E}-05$ & $9.46 \mathrm{E}-06$ & $9.17 \mathrm{E}-07$ & $1.29 \mathrm{E}-08$ & $1.26 \mathrm{E}-10$ \\
Tampa, FL & $5.39 \mathrm{E}-05$ & $8.72 \mathrm{E}-06$ & $2.84 \mathrm{E}-07$ & $2.28 \mathrm{E}-09$ & $1.83 \mathrm{E}-14$ & $1.56 \mathrm{E}-19$ \\
Phoenix, AZ & $3.75 \mathrm{E}-06$ & $7.29 \mathrm{E}-07$ & $4.89 \mathrm{E}-09$ & $1.83 \mathrm{E}-11$ & $1.09 \mathrm{E}-15$ & $7.50 \mathrm{E}-22$ \\
\hline
\end{tabular}


404 According to the data provided in Table 12, a second-order exponential function is a good fit to 405 the data in Ln-Ln space (i.e. Equation 8) in order to complete the tornado hazard curve which is 406 then expressed as:

$407 \quad \ln \left(H_{V}(v)\right)=\alpha e^{\beta \ln (v)}+\gamma e^{\lambda \ln (v)}$

408 In other words, the following equation is proposed here for the complementary cumulative 409 distribution function (CCDF) of tornado hazard curves only for wind speeds in excess of $22 \mathrm{~m} / \mathrm{s}$ 410 (50 $\mathrm{mph})$, which is satisfactory for tornado risk assessment since fragility functions have a value 411 of zero for wind speeds less than $22 \mathrm{~m} / \mathrm{s}(50 \mathrm{mph})$ :

$$
H_{V}(v)=\exp \left(\alpha(v)^{\beta}+\gamma(v)^{\lambda}\right) \quad v \geq 22 \mathrm{~m} / \mathrm{s}(50 \mathrm{mph})
$$

413 where, $H_{V}(v)$ is mean annual probability of exceeding 3-sec gust wind speed in tornadoes, $V$ is 3 414 second gust wind speed, $\alpha, \beta, \gamma$, and $\lambda$ are constants evaluated by fitting the above equation over 415 the hazard curve data.

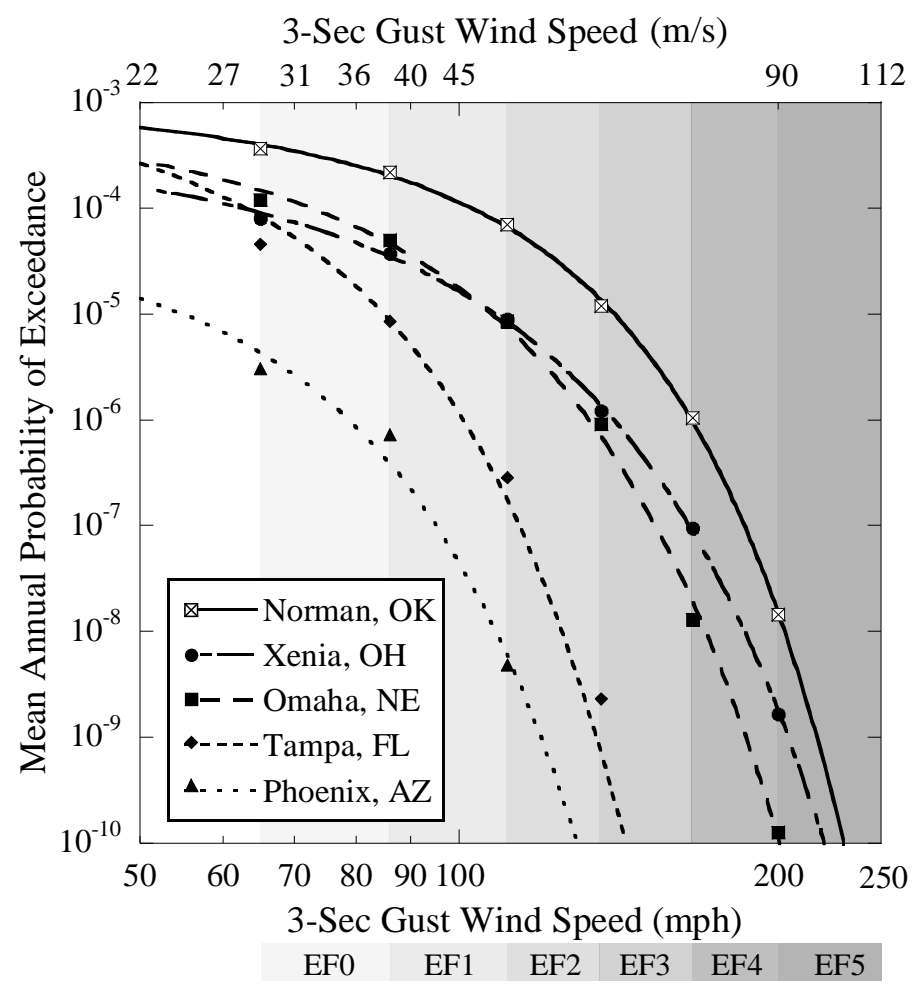


417 Figure 2. Tornado Hazard Curves for Selected Locations_-Dots show the values in Table 12

\section{4. Tornado Risk Assessment}

419 The probability of exceeding each damage state (DS) is then obtained by convolving the tornado 420 fragility with the tornado hazard curve, which can be expressed as:

$421 \quad P_{f}=\int_{x=0}^{x=\infty} \operatorname{Fr}(x) \cdot h_{I M}(x) d x=\int_{x=0}^{x=\infty} f r(x) \cdot H_{I M}(x) d x$

422 where, $\operatorname{Fr}(x)$ is the fragility function in the form of a cumulative distribution function (CDF)

423 which was described in Equation 1, $\operatorname{rr}(x)$ is the derivative of $\operatorname{Fr}(x)$ or the fragility function in the 424 form of a probability density function (PDF), $H_{I M}(x)$ and $h_{I M}(x)$ represent the CCDF and PDF of 425 the hazard, respectively, and $I M$ represents the intensity measure (e.g., 3-s gust wind speed). The 426 CCDF of tornado hazard was defined in Equation 9, and the hazard PDF can then be calculated 427 by:

$428 \quad h_{I M}(x)=\frac{d}{d x}\left[1-H_{I M}(x)\right]$

$429 P_{f}$ is probability of exceeding the DS in one year provided that the hazard curve is based on the 430 annual probability of exceeding an $I M$. Therefore, in order to get the $n$-year probability of 431 exceeding the DS, $P_{f}^{n}$, one can write:

$432 \quad P_{f}^{n}=1-\left(1-P_{f}\right)^{n}$

433 The Poisson distribution gives the same probability as the binomial distribution in Equation 12 434 for obtaining the $n$-year probability of exceeding the DS; however, it should be noted that if the 435 Poisson distribution is used then the "annual rate" should be used in lieu of the "annual 436 probability" for the hazard curve.

\section{5. Illustrative Example}

\section{5.1. School Building Archetype}

439 Xenia Senior High School located in Xenia, Ohio, was investigated as an unreinforced masonry

440 high school in this study in order to serve as a typical archetype for community risk and 441 resilience analysis. As mentioned earlier this high school was hit and destroyed by an F5 tornado 
442 in 1974 [26]. The construction types varied among the main parts of the school-original 443 building, and three additions (A, B, and C) [26]. The structural system for the original building 444 and addition B was a lightweight steel frame with open-web steel joists. Addition A had 445 loadbearing masonry walls with hollow-core precast concrete roof planks, and addition $\mathrm{C}$ had 446 precast concrete frames with concrete double-tee roof beams. Moreover, the girls' gym included 447 loadbearing masonry walls with precast concrete tee beams while the auditorium and the boys' 448 gym included loadbearing masonry walls with steel trusses. The school floor plan is shown in 449 Figure 3. However, the building studied in this paper is assumed to be a one story building with a 450 structural system consisting of unreinforced masonry walls constructed of 0.2 -meter (8-inch) 451 concrete masonry units and 0.1-meter (4-inch) face bricks. The roof consists of hollow-core 452 precast concrete roof planks (Figure 4). Moreover, this high school has three unreinforced 453 masonry long-span rooms, i.e. two gymnasiums (girls' gym and boys' gym) and one auditorium 454 constructed of 0.3-meter (12-inch) concrete masonry units and 0.1-meter (4-inch) face bricks, 455 which have roofs with precast concrete tee beams (Figure 4). Details of roofs and walls are 456 summarized in Table 13, and the beam cross-sections used in the roof system of the main 457 building and the girls' gym are shown in Figure 4.

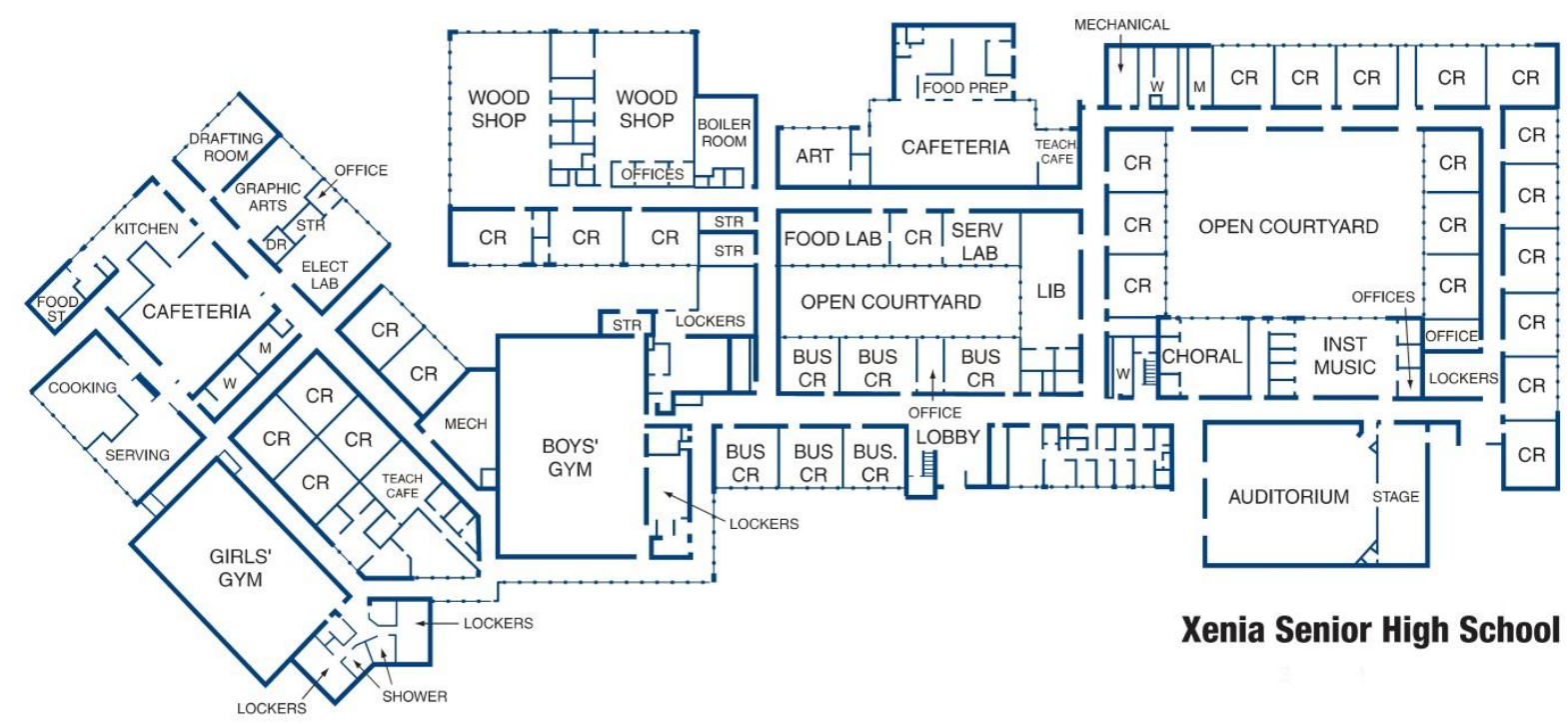

Figure 3. The High School Archetype Floor Plan (Excerpted from FEMA [26]) 

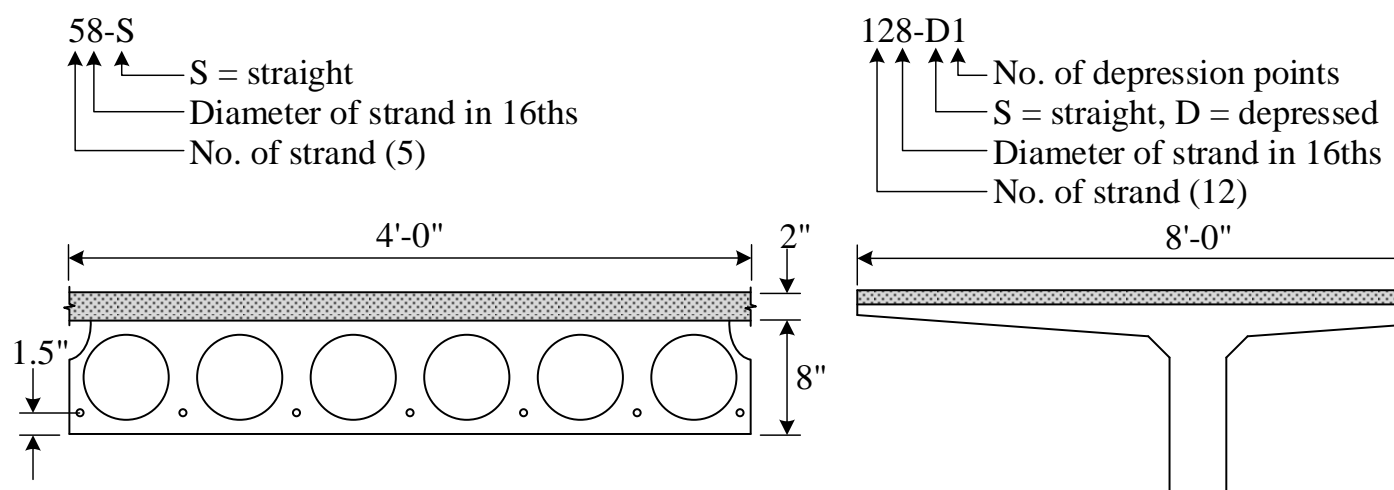

Hollow-Core Roof Plank

460

461

462

Figure 4. Cross-sections Used in the Roof System of the Main Building and the Girls' Gym

Table 13. High School Building Construction Details

\begin{tabular}{|c|c|c|c|c|c|}
\hline \multirow{2}{*}{ Building Part } & \multirow{2}{*}{ Dimensions } & \multirow{2}{*}{ Walls } & \multicolumn{3}{|c|}{ Precast Concrete Roof System* } \\
\hline & & & Beam Type & Name in PCI [47] & Strand Pattern \\
\hline Main & $\begin{array}{c}\text { Walls Height }= \\
4.3 \mathrm{~m}(14 \mathrm{ft}) \\
\text { Parapets Height }= \\
0.9 \mathrm{~m}(3 \mathrm{ft})\end{array}$ & 8' CMU & Hollow-Core & $4 \mathrm{HC} 8+2$ & $58-\mathrm{S}$ \\
\hline Girls' Gym & $\begin{array}{c}39 \mathrm{~m} \times 24.5 \mathrm{~m} \times 8 \mathrm{~m} \\
(128 \mathrm{ft} \times 80 \mathrm{ft} \times 26 \mathrm{ft})\end{array}$ & 12' CMU & Single Tee & $8 \mathrm{ST} 36+2$ & 128-D1 \\
\hline Boys' Gym & $\begin{array}{l}43 \mathrm{~m} \times 30.5 \mathrm{~m} \times 9 \mathrm{~m} \\
(140 \mathrm{ft} \times 100 \mathrm{ft} \times 30 \mathrm{ft})\end{array}$ & $12^{\prime} \mathrm{CMU}$ & Single Tee & $10 \mathrm{ST} 48+2$ & 188-D1 \\
\hline Auditorium & $\begin{array}{c}44 \mathrm{~m} \times 27.5 \mathrm{~m} \times 9 \mathrm{~m} \\
(144 \mathrm{ft} \times 90 \mathrm{ft} \times 30 \mathrm{ft})\end{array}$ & $12^{\prime} \mathrm{CMU}$ & Single Tee & $10 \mathrm{ST} 48+2$ & 148-D1 \\
\hline
\end{tabular}

$463 *$ Roof details can be found in PCI [47].

\section{6. Results and Discussion}

\subsection{Door and Window Fragility Analysis}

466 Monte Carlo Simulation (MCS) was used to develop the school building fragility for each 467 damage state, and the details of the procedure are presented in flowchart form in Figure 5. Based 468 on the three limit states presented in Table 10 for doors and windows (the third column), the 469 fragility curves of these three damage indicators were developed for both the enclosed and 470 partially enclosed building condition. Based on the discussion in section 2.2, the enclosed or 471 partially enclosed condition of building has no effect in the wind loads calculation in Approach 472 A (except for calculating the lateral pressures on MWFRS), but they affect wind loads related to 473 Approach B. A total of 120 doors and windows were considered in the analysis, specifically 20 
474 doors and 100 windows. Fragility curves are presented in Figure 6 for limit states 1-3 as a 475 function of 3 -sec gust wind speed. Since more than 25 percent failure of doors and windows are 476 assumed to occur in damage state 4, they have no effect on the fragility curve for this damage 477 state.

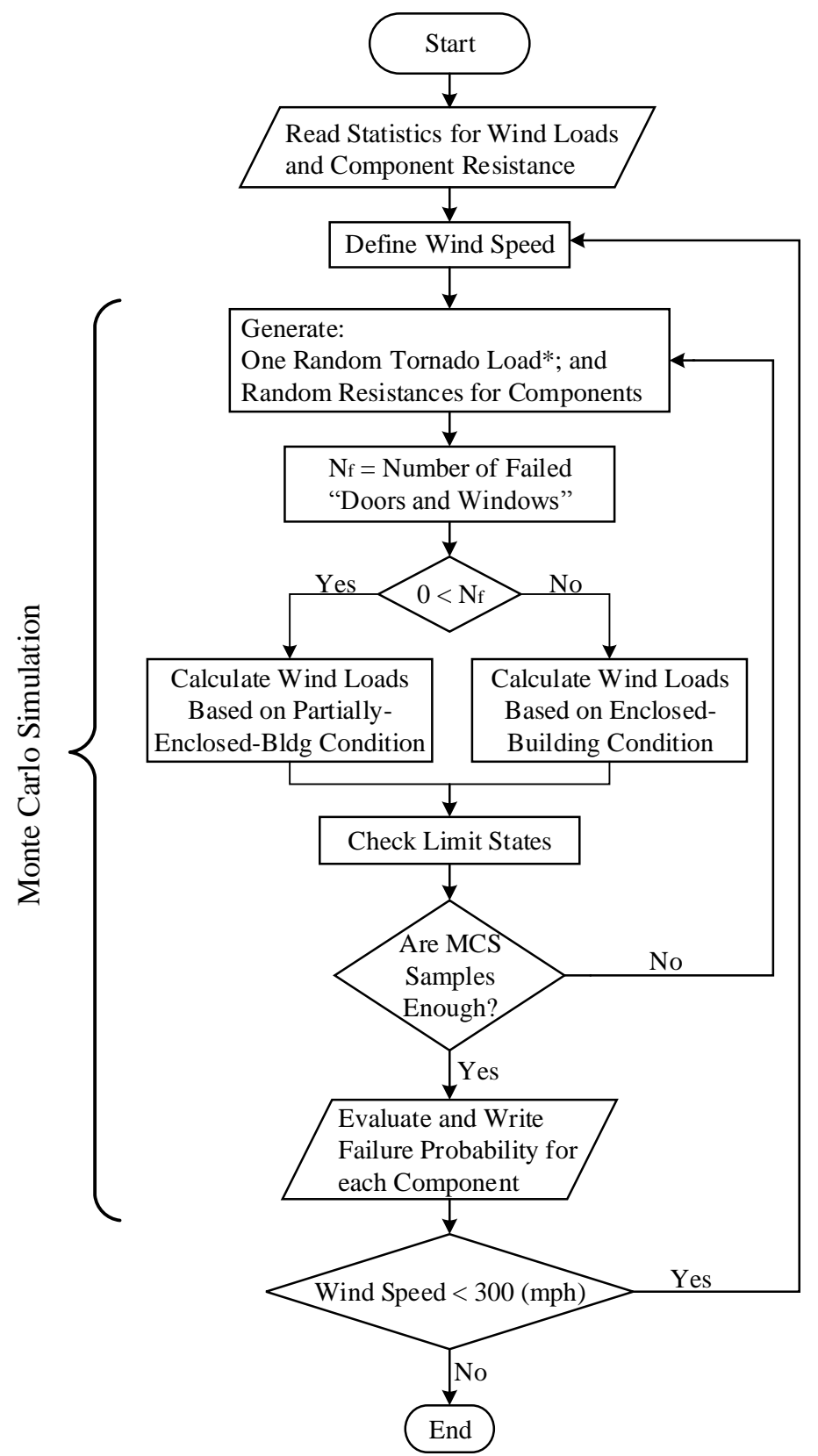

* It is noted that for a large building, loads may differ from one side of the building at a point in time. However, since the peak load from a 3-sec gust wind speed is used, i.e. a static analysis, the spatial effect across the building is neglected in this study.

Figure 5. Flowchart of Developing Fragility Curves 


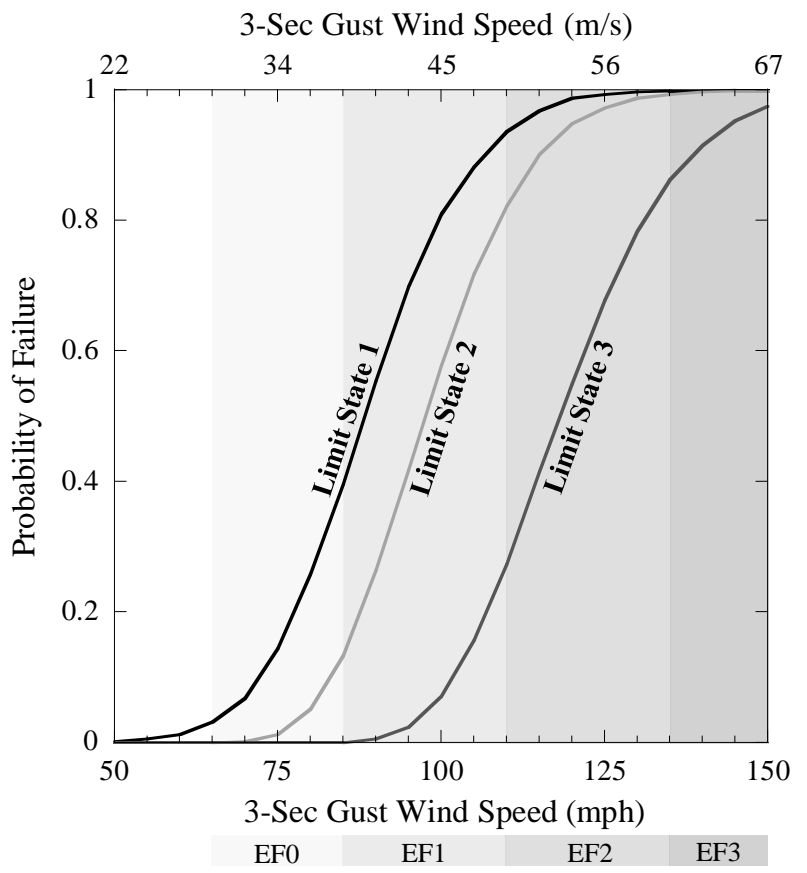

(a) Approach A Fragilities

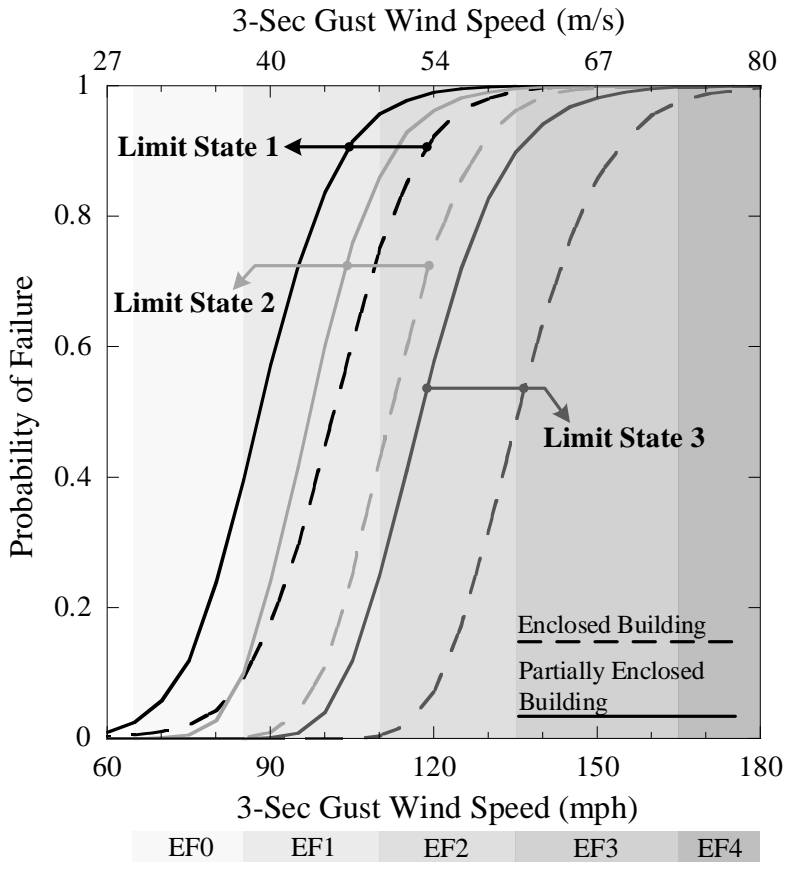

(b) Approach B Fragilities

Figure 6. "Doors and Windows" Fragility Curves

\subsection{Roof Cover Fragility Analysis}

Observations of roof cover damage in hurricanes has indicated that because of building aerodynamics the highest uplift pressures occur at roof corners, the second highest at the roof perimeter, and the remainder of the roof has even lower pressures [28, 54]. Investigation following tornadoes appears to be somewhat consistent [6]. Therefore, based on limited knowledge of tornado pressures compared to hurricanes at this stage there is no logical reason to use different pressure zones beyond those which are defined by ASCE 7-10 for roof wind load calculations. Figure 7 shows the failure probability of roof perimeter flashing and the probability of roof cover peeling or bubbling for the different zones indicated in this Figure. According to Figure 7, for Approach A fragilities, the roof cover has a 16\% probability of peeling or bubbling for only a $45 \mathrm{~m} / \mathrm{s}$ (100 mph) 3-sec gust wind speed in zone 1 , and it has a significantly higher peeling or bubbling probability in zone 2 and 3, namely $85 \%$ and $100 \%$, respectively. On the other hand, using Approach B will result in no failure in zone 1', and 5\%, 35\%, and 85\% probability of failure respectively in zones 1 to 3 for roof peeling and bubbling. 


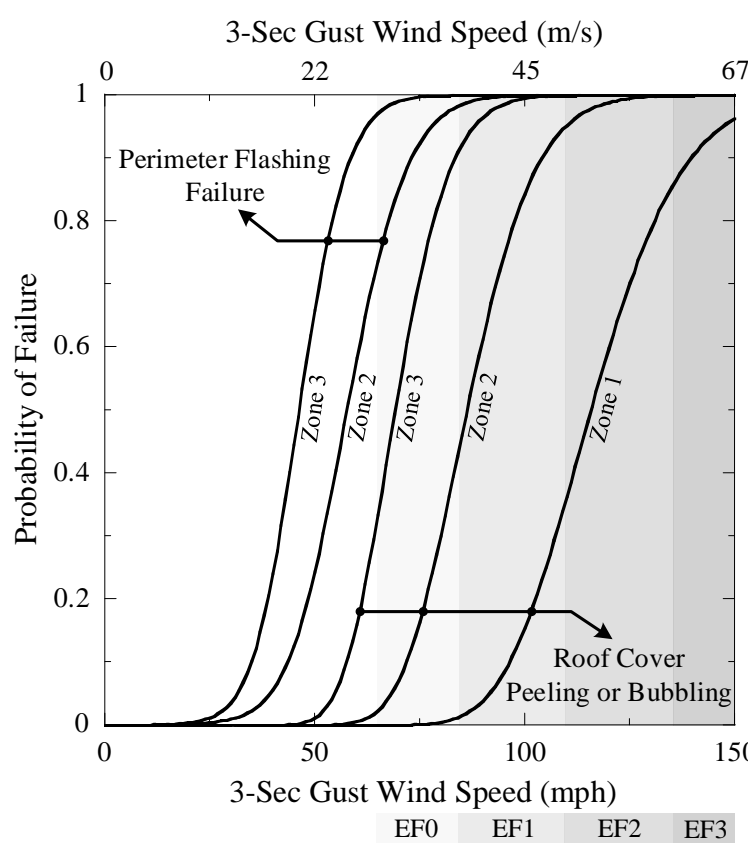

(a) Approach A Fragilities

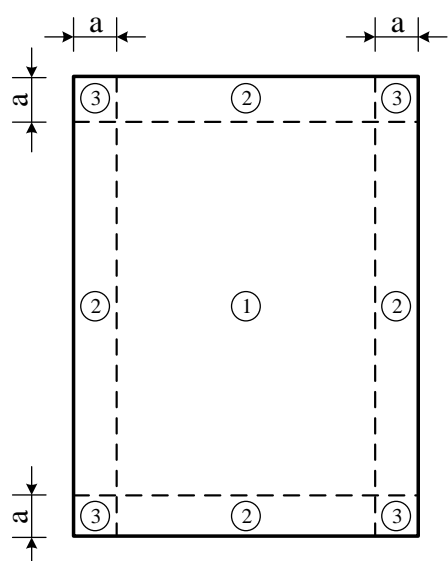

Three zones defined in ASCE 7-10 [18] in order to find external pressure coefficients, $\mathrm{GC}_{\mathrm{p}}$, on components and cladding of flat roofs.

a: $10 \%$ of least horizontal dimension or $0.4 \mathrm{~h}$, whichever is smaller, but not less than either $4 \%$ of least horizontal

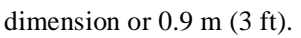

h: Eave height.

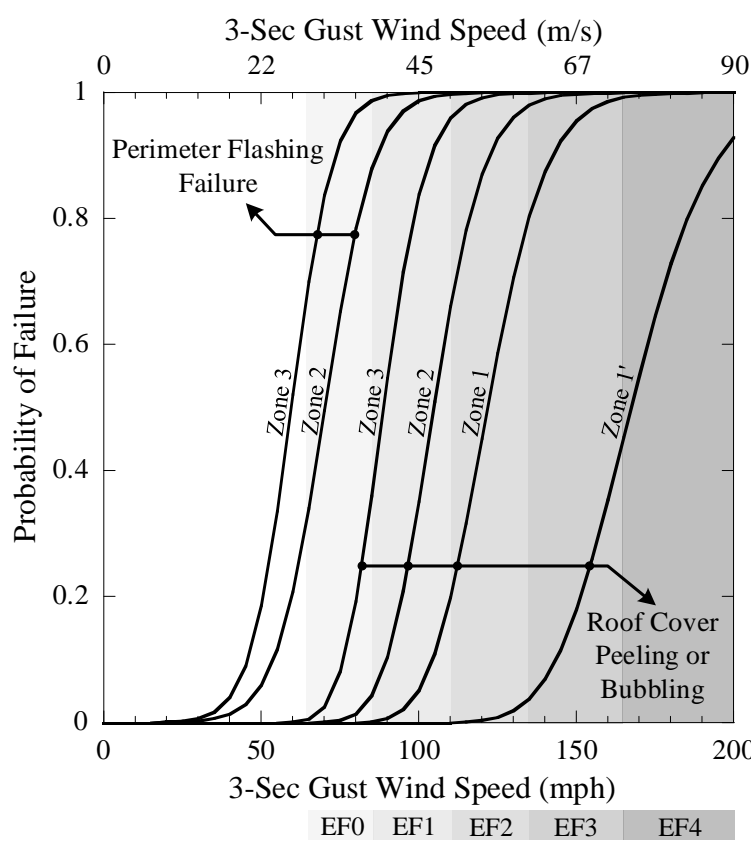

(b) Approach B Fragilities

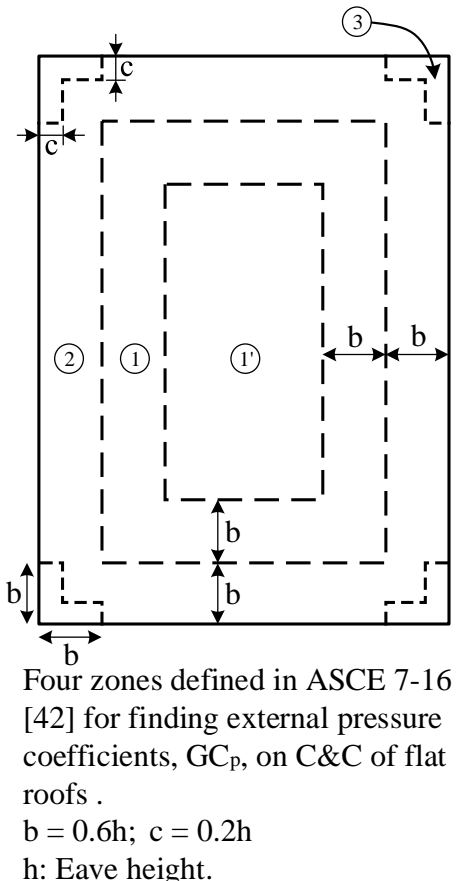

$\mathrm{h}$ : Eave height.

Figure 7. Built-Up Roof (BUR) Covers Probability of Failure

498 Roof cover fragility curves for the limit states defined in Table 10 (the second column) are presented in Figure 8. In order to calculate the roof cover probability of failure, the roof area is divided into square areas. Monte Carlo Simulation was implemented in the same process as displayed in Figure 5, and the failure condition of each square areas was found by comparison of 
randomly generated values of resistance and load using roof cover resistance and wind loads statistics. It is worth mentioning that, although areas are considered to be statistically independent with respect to roof cover resistance, they are completely dependent through their exposure to wind loads. As indicated in the flowchart in Figure 5, in order to find the binary failure condition for the areas, all randomly generated resistances were compared to a single random demand (i.e., equal velocity pressure, $q_{h}$, for all the roof area in each iteration, but different wind pressure, $\mathrm{p}$, for different zones) in each MCS sample (the first process in Monte Carlo Simulation part of flowchart shown in Figure 5). Similar to the doors and windows, roof cover has no effect on the fragility curve for damage state 4 since more than 50 percent failure of 511 the roof cover is assumed to be included in DS 4 for roof cover.

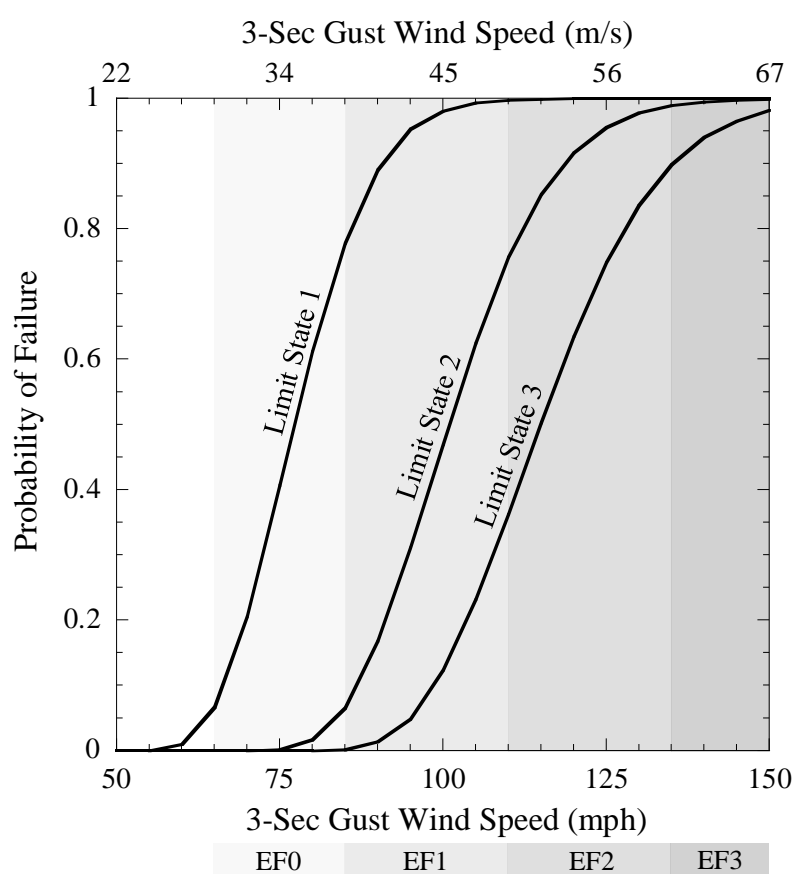

(a) Approach A Fragilities

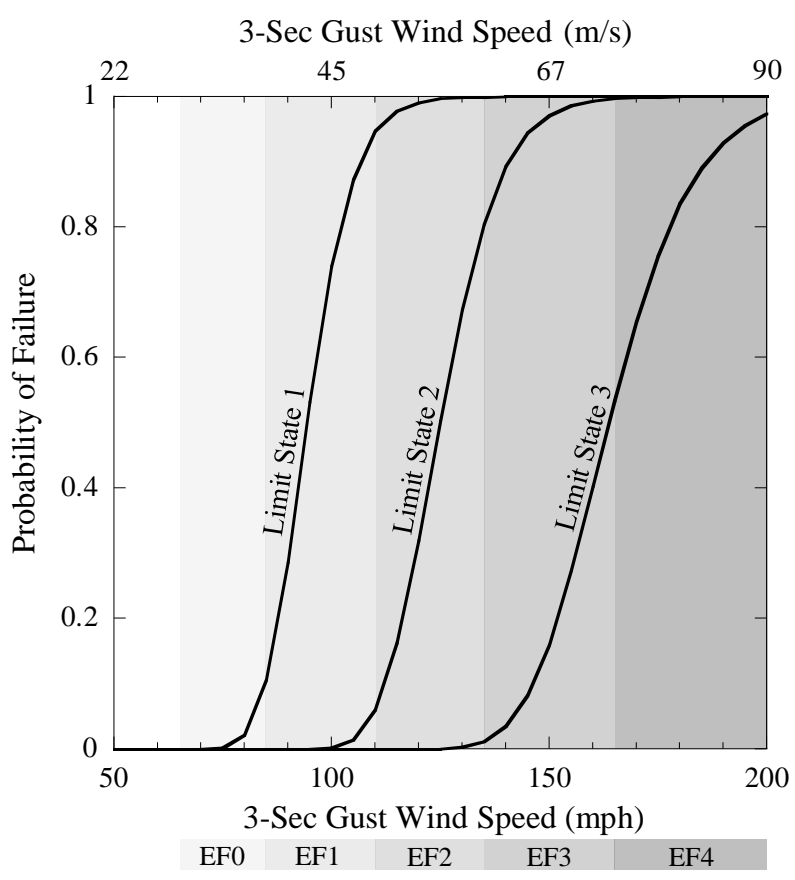

(b) Approach B Fragilities

Figure 8. Built-Up Roof Covers Fragility Curves

514 Although the external pressure coefficients for roof $\mathrm{C} \& \mathrm{C}$ were increased for zones 1 to 3 in 515 ASCE 7-16, the fragilities for roof cover based on ASCE 7-16 are not necessarily more fragile 516 than those based on ASCE 7-10 since a new zone (i.e. zone 1') was defined in ASCE 7-16 which 517 has lower external pressure coefficient than the three zones in ASCE 7-10 [18]. Buildings with 518 the smaller horizontal dimension less than $2.4 \mathrm{~h}$ do not include zone 1', therefore their fragilities 519 are shifted left when ASCE 7-16 coefficients are used. However, in a building which major part of the roof is zone 1', although limit state 1 and 2 may have a higher failure probability based on 
521 ASCE 7-16 coefficients, they might have a lower probability for limit state 3 since zone 1 ' has a 522 significant contribution to this limit state (i.e. more than $50 \%$ of the roof cover fails).

\section{6.3. Roof Structural Fragility Analysis}

524 During intense tornadoes, roofs can be lifted off and can re-settle often collapsing as the result of 525 significant wind uplift pressure. The weight of building components (e.g., roof precast concrete 526 beams in the school building in the present study) helps resist uplift loads. Consequently, these 527 components usually survive extreme winds if they are also well tied to all other building 528 components. However, concrete roof panels that are not properly connected or reinforced have 529 failed during severe winds. Conventionally, precast concrete beams are designed for gravity 530 loads (i.e. positive moment), but not for the uplift loads (i.e. negative moment). Hence, the 531 combined effects of large wind uplift forces and the beams own pre-stressing forces can result in 532 lifting of the panels and thus negative bending failure.

533 Two modes for roof panel failure were considered in this study and include the roof-to-wall 534 connection failure and the bending failure of the roof deck under negative moment caused by 535 tornado wind uplift pressures. The roof structural failure probability, $P_{r s f}$, was evaluated based on 536 the union of these two failure probabilities defined as:

$$
P_{r s f}=P_{c f} \cup P_{b f}
$$

538 where, $P_{c f}$ is probability of roof-to-wall connections failure, and $P_{b f}$ is probability of bending 539 failure of the roof beam. These two events are not statistically independent since they are 540 subjected to the same wind uplift pressure, which was considered in the analysis as discussed 541 earlier.

542 MCS were utilized to evaluate survivability of a beam in bending and connections (or to 543 calculate $P_{c f}$ and $P_{b f}$ ), and subsequently the survivability of the roof (or the probability of roof 544 failure). Structural analyses were conducted under the assumption of a simply supported beam 545 (i.e., simply supported single tee beams for the boys and girls gymnasiums as well as auditorium, 546 and simply supported hollow-core roof panels for the rest of the building) in order to find 547 demand forces. Figure 9 shows $P_{c f}, P_{b f}$, and $P_{r s f}$ as a function of 3-sec gust wind speed for the 548 boys' gymnasium roof. As indicated in Figure 9, the fragility curves for the union of bending 
549 failure and connection failure lies on the fragilities of the bending failure, which reveals the fact 550 that these two events are stochastically dependent.

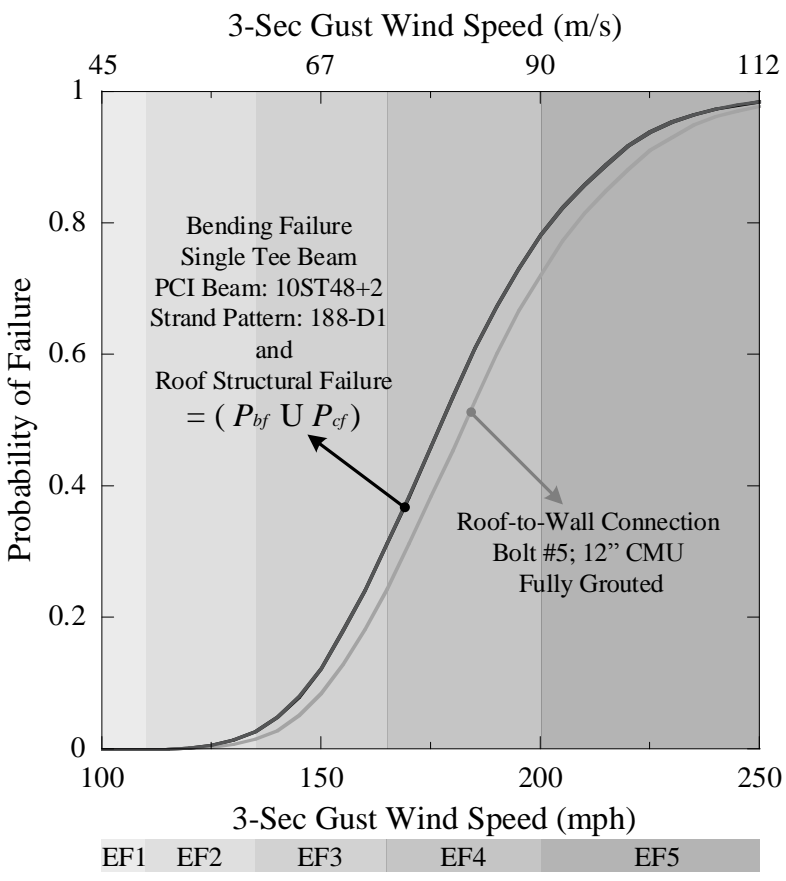

(a) Approach A Fragilities

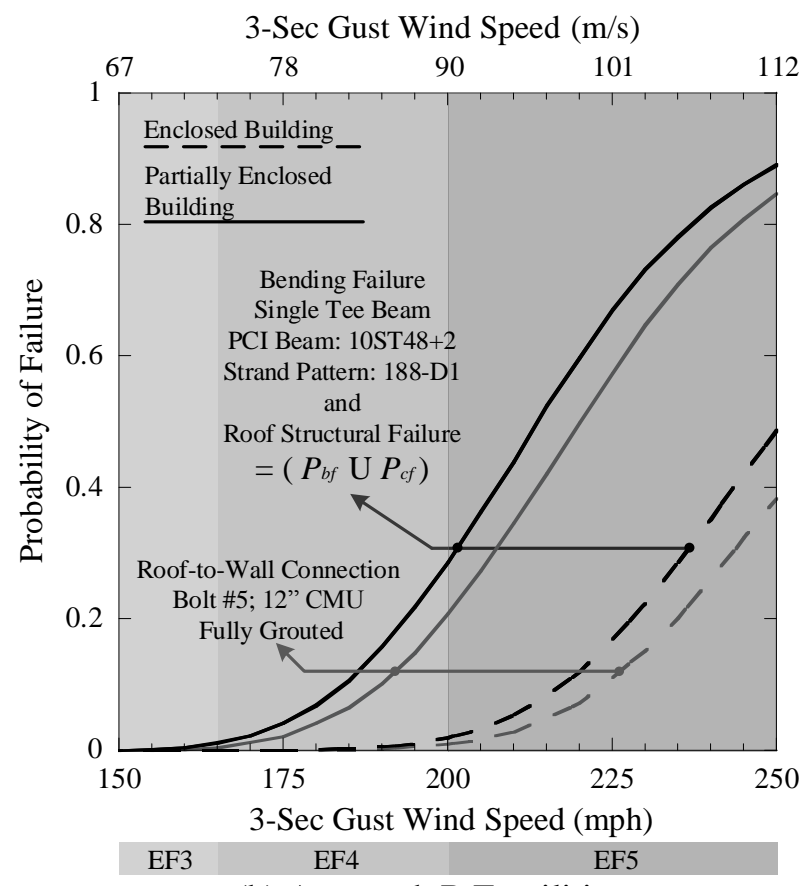

(b) Approach B Fragilities

Figure 9. Structural Roof Fragility Curves for the Boys' Gymnasium

553 The main point here is that all the single beams constructed in a roof are somewhat tied together

554 such that they cannot be assumed to be statistically independent. Thus, the influence of all the 555 roof beams is inherently applied as a simply supported beam assumption with bending failure at 556 midspan. In other words, the curves in Figure 9 were based on a single tee beam, but these 557 curves are felt to be representative of the failure probability of the roof. In this study, four 558 separate roof portions were assumed, including the boys' gym roof, girls' gym roof, auditorium 559 roof, and roof for the rest of the building. The total probability of roof structural failure for the 560 school was calculated by the union of roof structural failure for these four parts which are 561 stochastically dependent as discussed throughout. Figure 10 shows the roof structural fragilities 562 for the school building. 


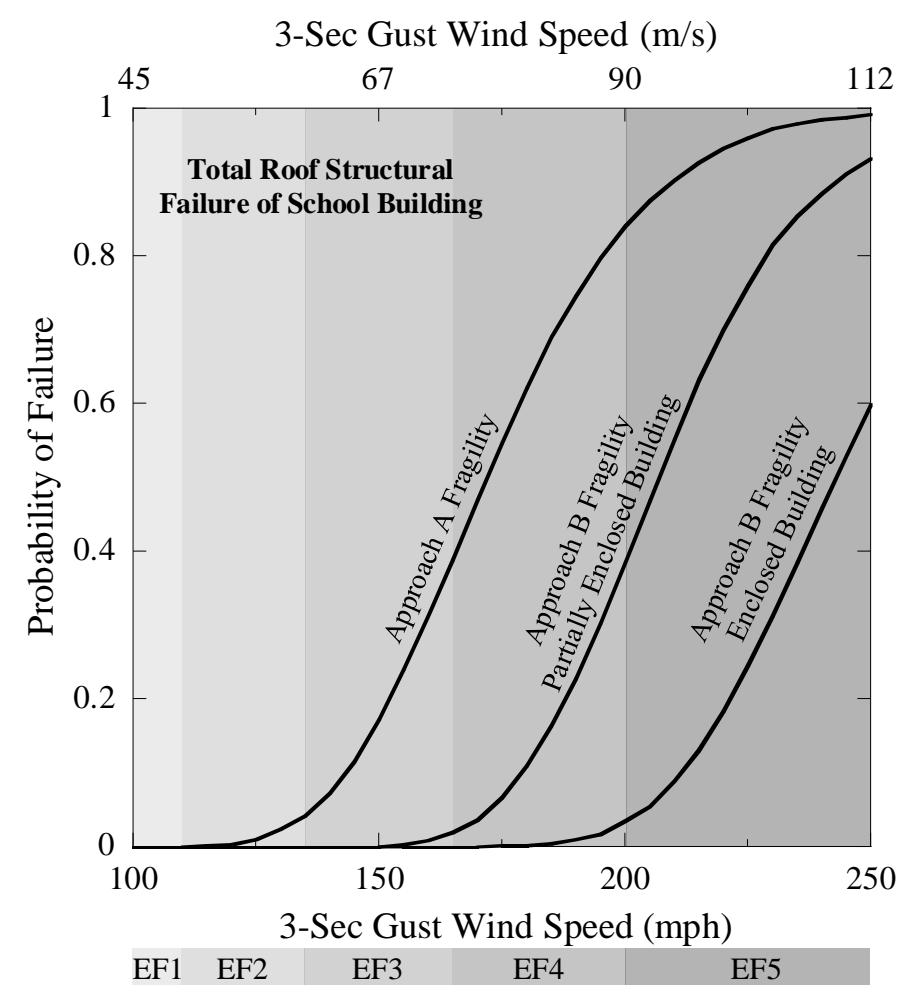

Figure 10. Roof Structural Fragility Curve for School Building

\subsection{Fragility Analysis of Masonry Walls}

566 As mentioned before, five types of masonry construction, labeled URM1 to URM5, (with 567 properties summarized in Table 5) are considered in this study in order to provide applicability 568 across the range of masonry construction seen in the United States. In order to analyze masonry 569 walls subjected to tornado wind loads, a $0.3 \mathrm{~m}$ (1 ft.) strip of wall was assumed as a simply 570 supported beam typical to what is done conventionally in design to wind load for masonry walls. 571 In this study, each non-load-bearing wall and load-bearing wall has four representative models 572 corresponding to each part of the school (i.e. boys' gym, girls' gym, auditorium, and the rest of 573 the building). The school building fragilities for each non-load-bearing wall and load-bearing 574 wall were calculated by the union of the fragilities for these parts. 


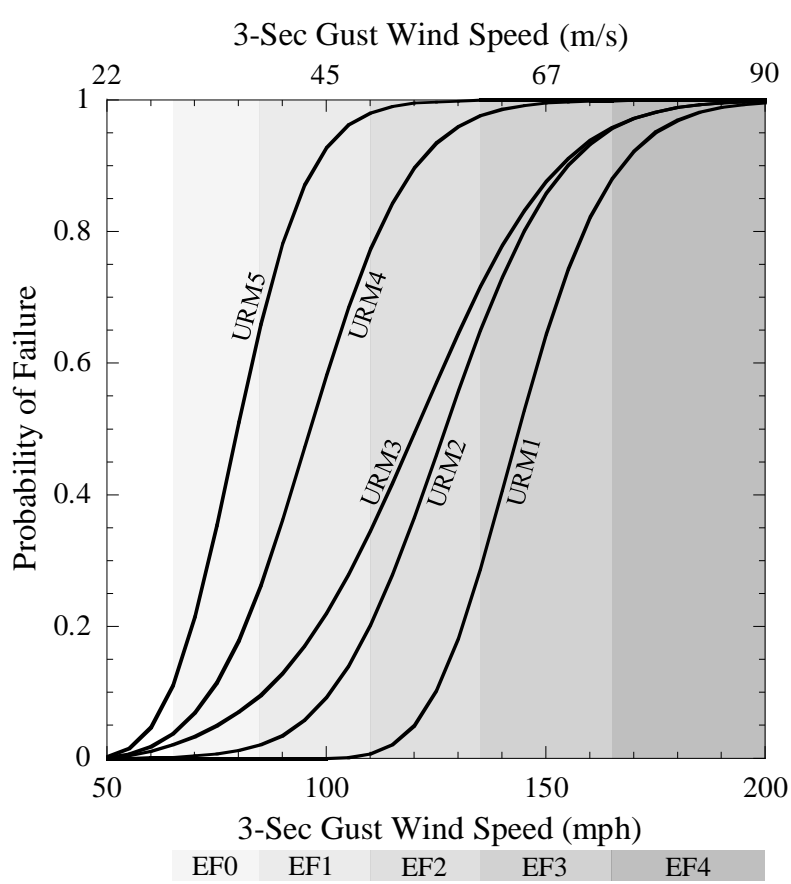

(a) Partially Enclosed Building Approach A Fragilities

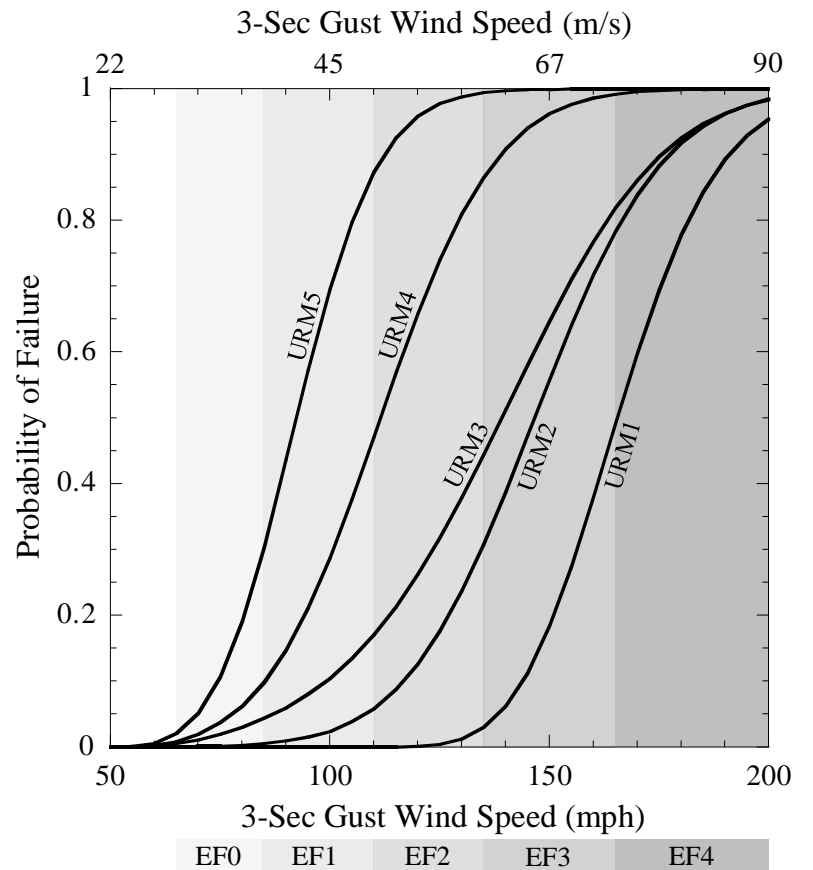

(c) Enclosed Building Approach A Fragilities

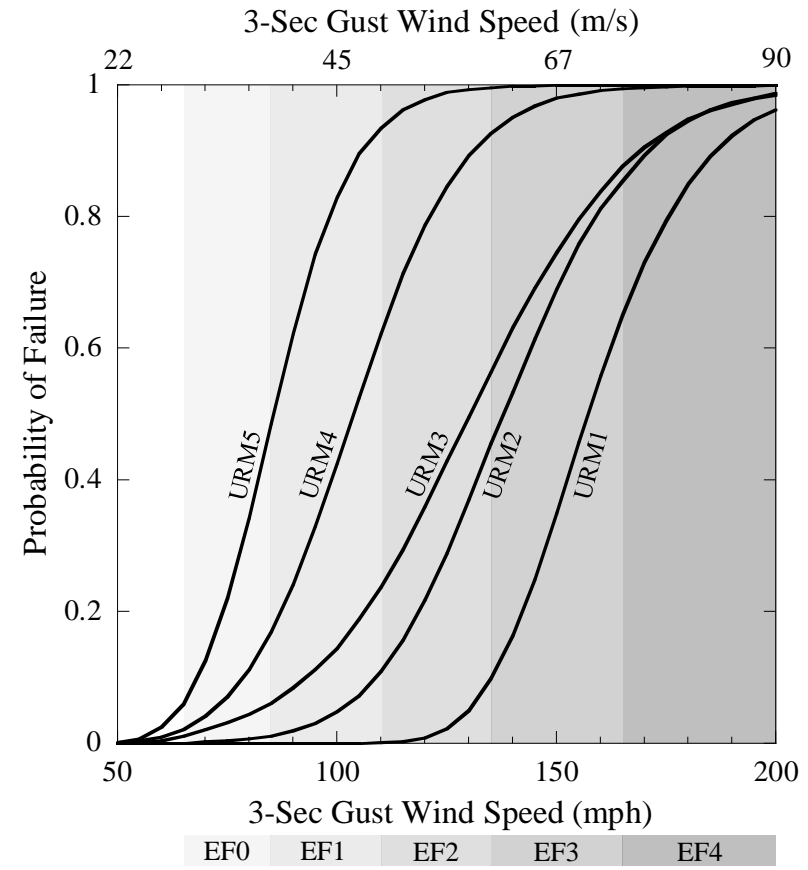

(b) Partially Enclosed Building Approach B Fragilities

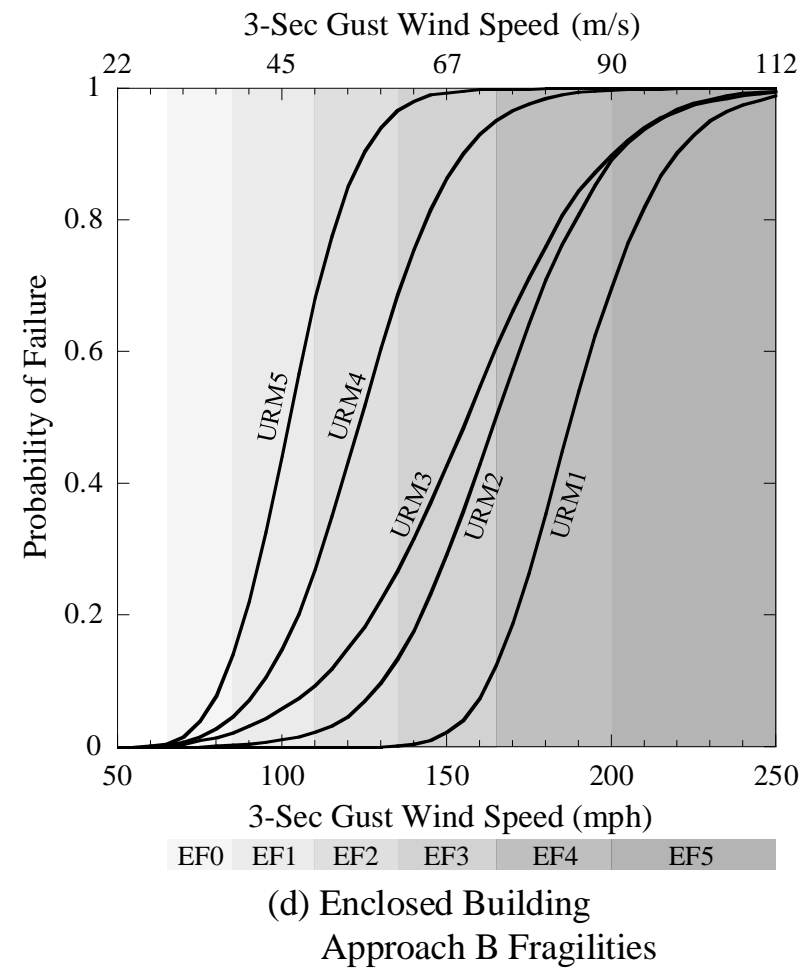

Figure 11. Unreinforced Masonry Load-Bearing Wall Fragility Curves for the Boys' Gymnasium 577

(5 Different Material Assumptions) 
579 To this point in the analysis, the failure probability of each damage indicator in Table 10 has 580 been calculated for both an enclosed building and partially enclosed building condition. The 581 individual component failure can then be used to develop the school building fragility curves as 582 defined in Table 10 by MCS and based on the assumption that each damage state is defined as 583 the occurrence of any of the shaded damage indicators in a given row.

584 Internal pressure in buildings during a tornado is affected by two phenomenon, wind flow into 585 the building and static pressure drop in the tornado vortex. Although the latter case was not explicitly considered in this study, the effect of wind flow on internal pressure was included in the calculation of wind-induced forces by considering different values for the internal pressure 588 coefficient when the building is either enclosed or partially enclosed. As discussed in section 589 2.2., this is effective only in load calculation using Approach B as well as forces on walls in 590 Approach A. If doors and windows on all sides of the building remain undamaged and closed 591 during a tornado, wind into the building will be minor. Once there is a breach in the building 592 envelope from the failure of a door or a window, or penetration of the roof or walls, the wind 593 pressure in the building increases. In summary, in the current study, the process to generate 594 school building fragility curves in each of the damage states works under the assumption that any 595 failure of doors or windows results in a partially enclosed building condition.

596 Finally, in Figure 12 to Figure 14, five fragility curve groups for five building types termed 597 URM1 to URM5 based on their masonry material types are presented. Since damage states 1 and 5982 are not dependent on the masonry material, which is the only difference for the buildings, all 599 the school buildings have the same fragility curves for damage states 1 and 2. On the other hand, 600 damage states 3 and 4 have the non-load-bearing wall and load-bearing wall as one of their 601 damage indicators; therefore, fragility curves related to these damage states are dependent on the 602 masonry construction, and any changes in masonry material statistics result in a change in their 603 fragility curves. Therefore, one can see in Figure 12 to Figure 14 that the fragility curves for 604 URM3 to URM5 cross each other since the masonry construction does not perform as well as the 605 roof cover. In seismic fragility analysis, this will typically not occur if only one engineering 606 demand parameter is used (e.g. inter-story drift ratio). 

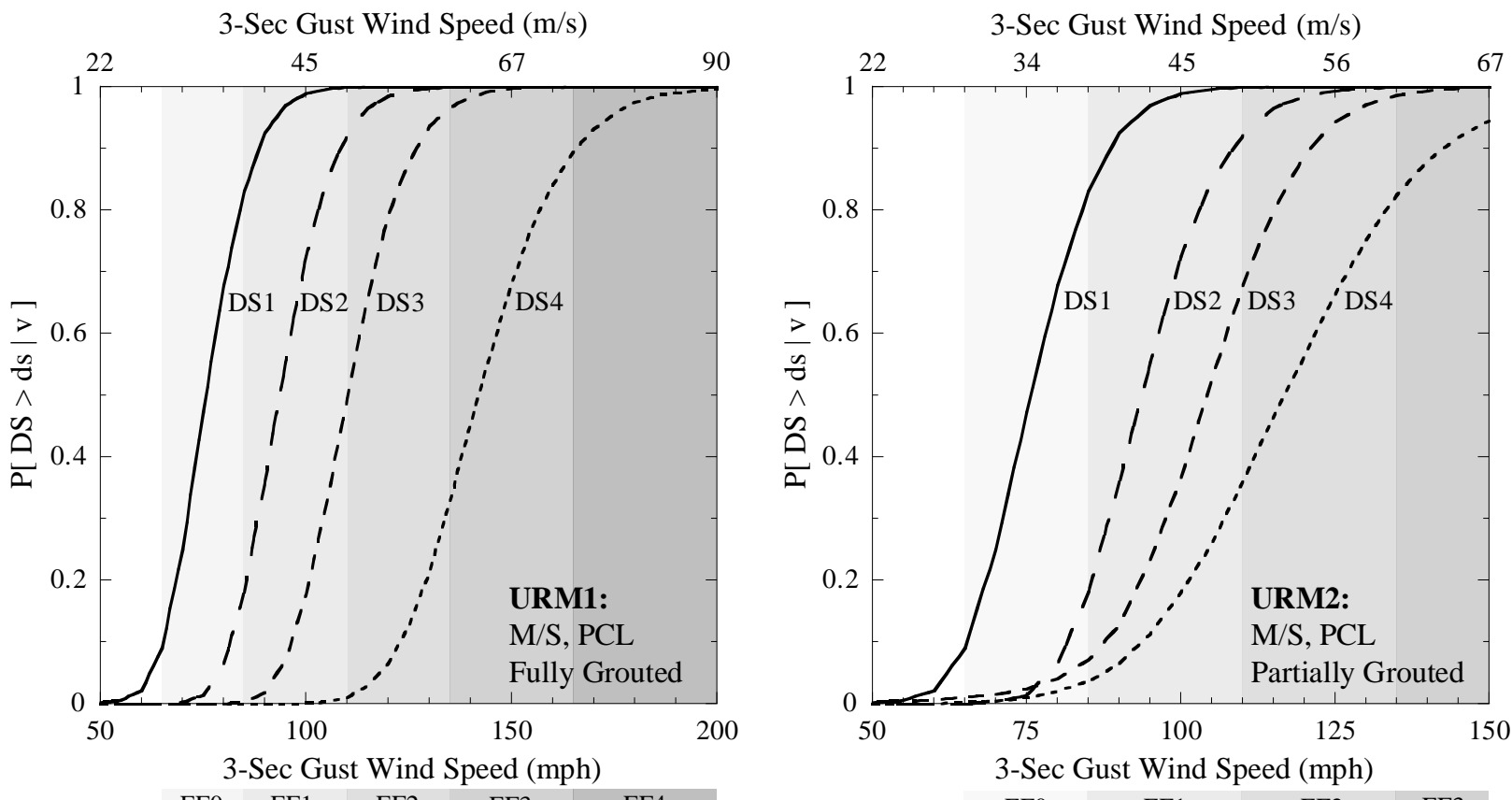

$\begin{array}{lllll}\mathrm{EF} 0 & \mathrm{EF} 1 & \mathrm{EF} 2 & \mathrm{EF} 3 & \mathrm{EF} 4\end{array}$

$\begin{array}{llll}\text { EF0 } & \mathrm{EF} 1 & \mathrm{EF} 2 & \mathrm{EF} 3\end{array}$

3-Sec Gust Wind Speed (m/s)
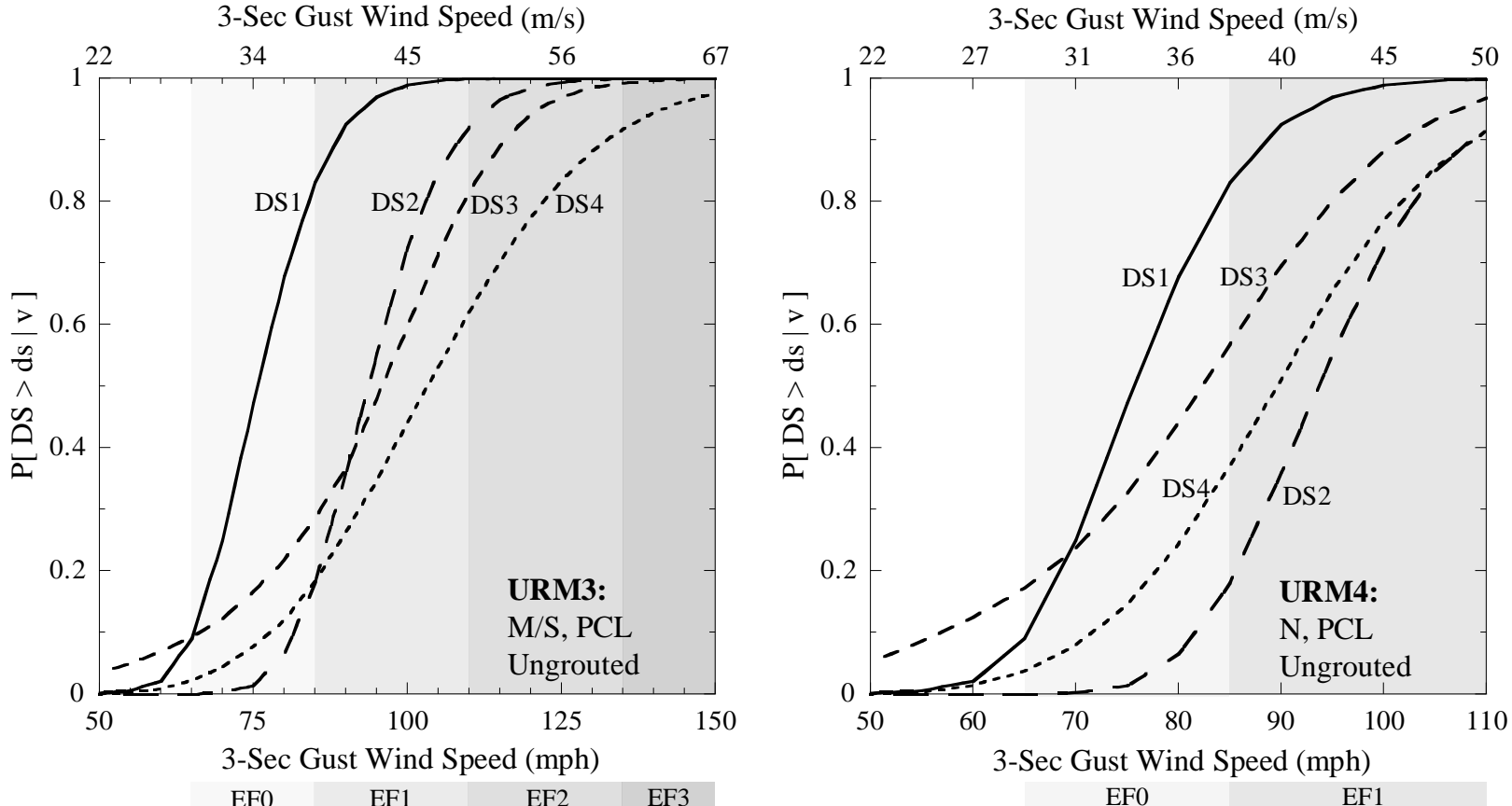

608

609

Figure 12. School Building Fragility Curves (Approach A) for Different Masonry Material Assumptions 

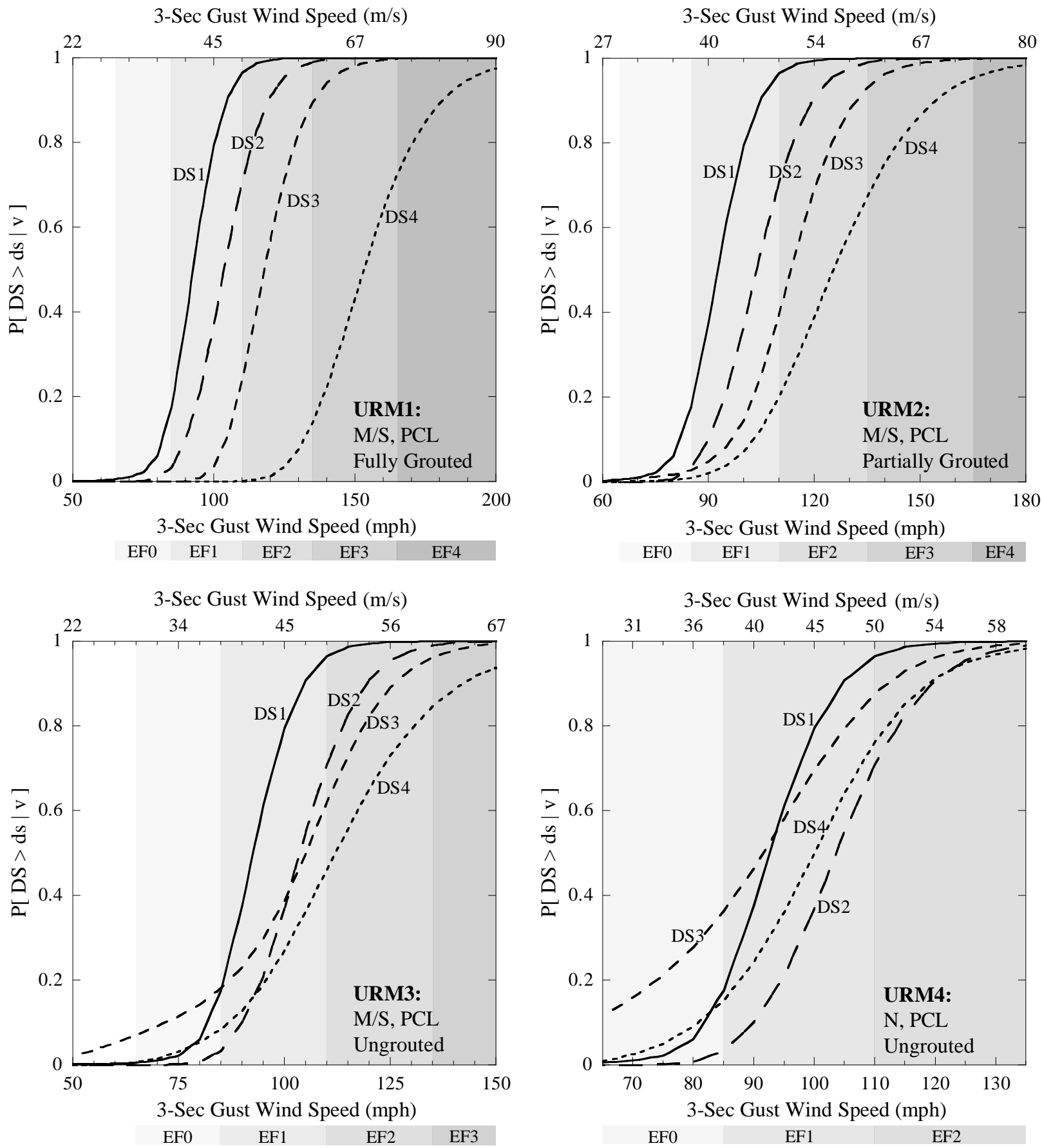

Figure 13. School Building Fragility Curves (Approach B) for Different Masonry Material 


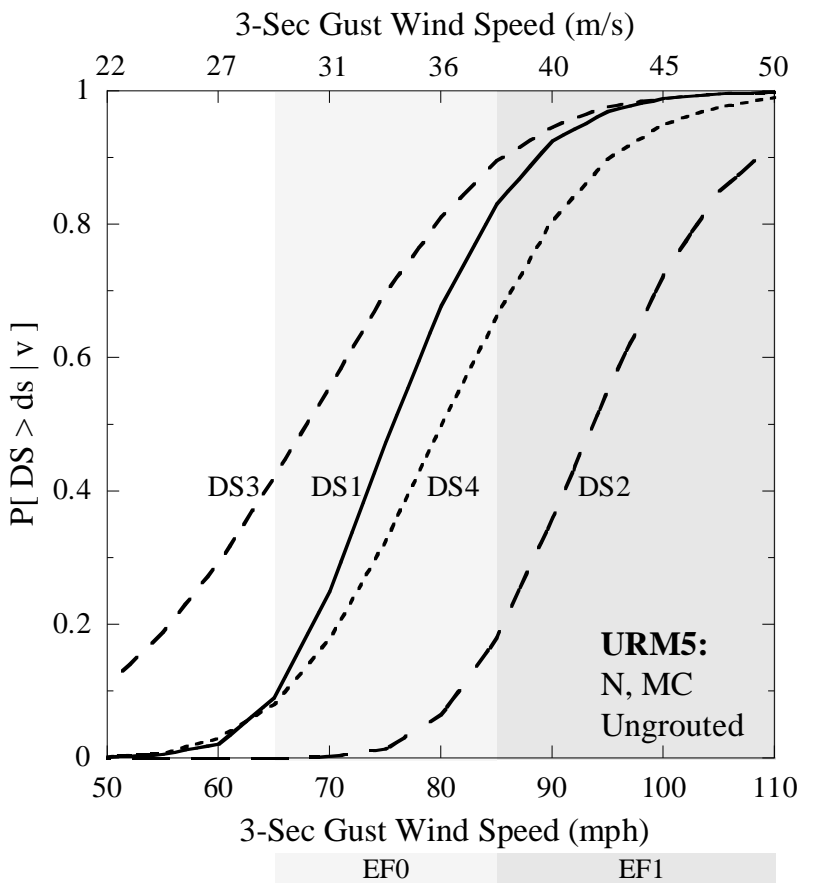

(a) Approach A Fragilities

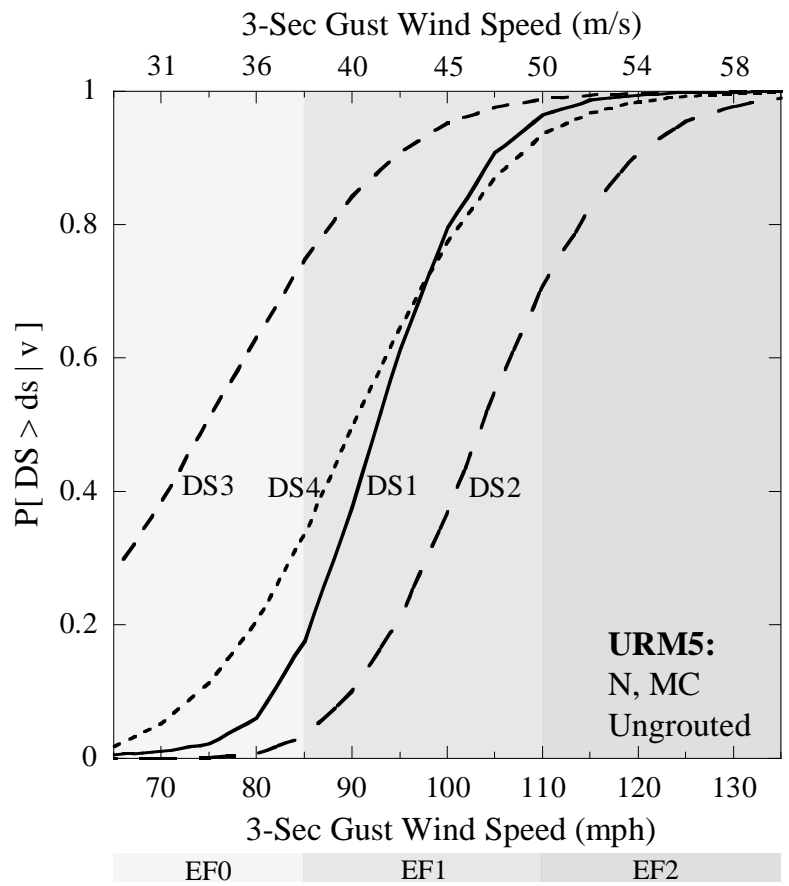

(b) Approach B Fragilities
613

614

615 The fragilities presented in this paper can be included in the building stock as a representative 616 archetype school building for community risk and resilience modeling. While there is no way to 617 explicitly confirm the accuracy beyond the physics and mechanics basis of the model and 618 process, some level of validation based on damage observation following tornadoes is possible. 619 The school in Xenia, Ohio was subjected to winds in excess of $90 \mathrm{~m} / \mathrm{s}(200 \mathrm{mph})$ and its roof 620 was destroyed. Inspection of Figure 10 shows that there is between a $40 \%$ and $85 \%$ chance of 621 severe damage to the roof system analyzed in this study which was modeled after that school, 622 indicating a likely causal relationship.

623 It should be noted that eventual comparison to Eurocode is warranted but not included herein 624 because the Haan et al. [14] tornado amplification coefficients used for analysis are only 625 applicable to ASCE 7. Additionally, approximately $75 \%$ of tornadoes worldwide occur in the 626 U.S. east of the Rocky Mountains. Therefore, in the interest of brevity this comparison is not 627 included herein.

628 It is well known that even moderately intense and certainly intense tornadoes form debris clouds 629 at the base resulting in objects becoming missiles. Experience confirms that heavy and large 630 objects such as cars and buses can become debris at high wind speeds and cause significant 
631 damage. On the other hand, light objects can also penetrate the building envelope, resulting in a 632 change in internal pressure. Although windborne debris clearly plays a significant role in tornado

633 fragility assessment of structures, its effects are beyond the scope of the current study and will be 634 investigated in future studies.

\subsection{Risk Assessment of School Buildings}

636 The probability of exceeding each damage state is evaluated herein by convolving a tornado 637 hazard curve [53] and the masonry school building fragilities for each damage state. Figure 15 638 illustrates risk assessment of building type URM3 located in Norman, Oklahoma by convolution 639 integral. The shaded area represents the probability of exceeding damage state 4 in one year 640 which is equal to $0.0126 \%$ (i.e. 1.26E-04). Since the hazard curves were developed based on 641 annual probabilities, the $P_{f}$ would be the exceedance probability per year. Then, 50-year 642 probabilities of exceeding damage states are calculated using Equation 12. Therefore, school 643 building type URM3 located in Norman will exceed damage state 4 with a probability of $0.63 \%$ 644 in 50 years which is approximately equal to an 8000-year return period.

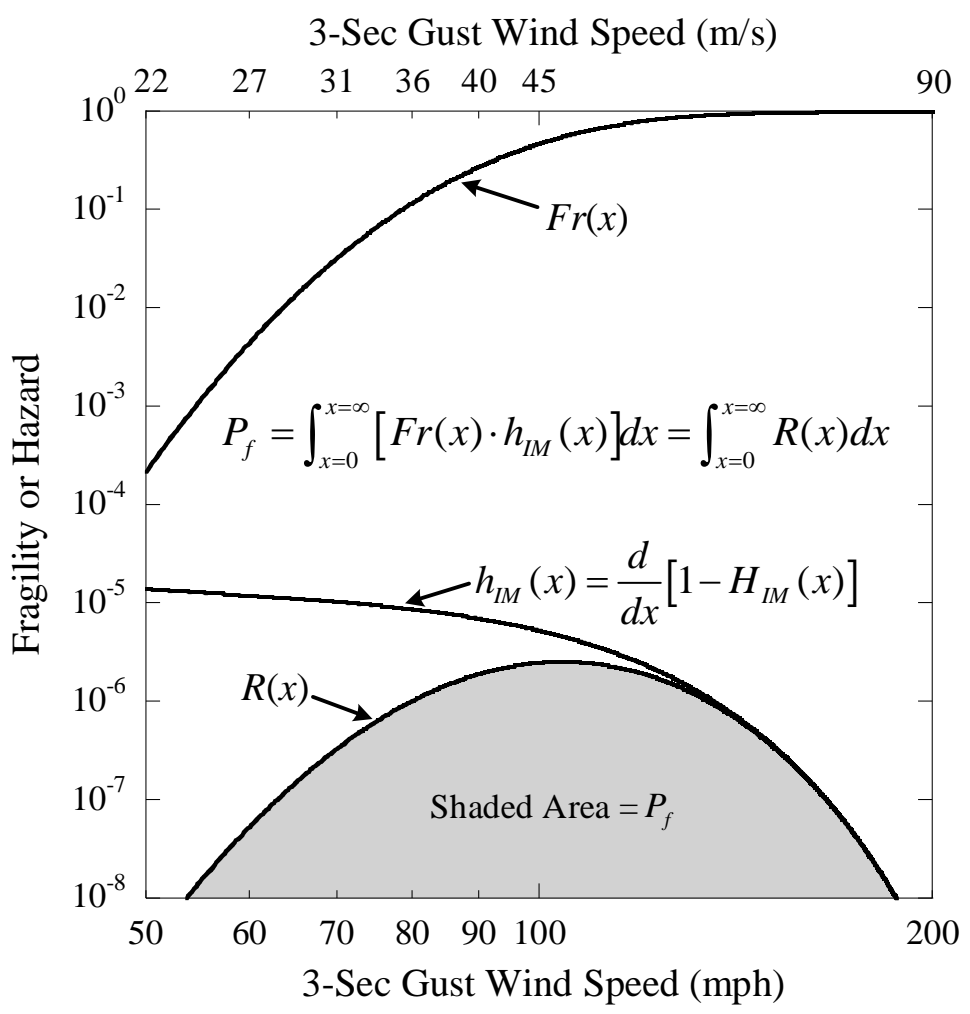


647 Damage state exceedance probabilities in 50 years were calculated and tabulated in Table 14 for 648 all combinations of building type and all selected cities, although in theory, some combinations 649 would not occur for modern building codes. As previously mentioned, DS1 and DS2 do not 650 change for the five building types since based on their definition they are not based on masonry 651 materials.

652 Table 14. School Buildings 50-year Probability of Exceeding each Damage State (in \%) for 653

\begin{tabular}{lcccccc}
\hline \multirow{2}{*}{ City } & \multirow{2}{*}{ Damage State } & \multicolumn{5}{c}{ Building Type } \\
\cline { 3 - 7 } & & URM1 & URM2 & URM3 & URM4 & URM5 \\
\hline \multirow{4}{*}{ Norman, OK } & DS1 & 1.46 & 1.46 & 1.46 & 1.46 & 1.46 \\
& DS2 & 0.78 & 0.78 & 0.78 & 0.78 & 0.78 \\
& DS3 & 0.38 & 0.55 & 0.92 & 1.34 & 1.94 \\
& DS4 & 0.07 & 0.34 & 0.63 & 0.96 & 1.30 \\
\hline \multirow{4}{*}{ Xenia, OH } & DS1 & 0.30 & 0.30 & 0.30 & 0.30 & 0.30 \\
& DS2 & 0.13 & 0.13 & 0.13 & 0.13 & 0.13 \\
& DS3 & 0.05 & 0.09 & 0.18 & 0.29 & 0.46 \\
& DS4 & 0.01 & 0.05 & 0.11 & 0.18 & 0.26 \\
\hline \multirow{4}{*}{ Omaha, NE } & DS1 & 0.46 & 0.46 & 0.46 & 0.46 & 0.46 \\
& DS2 & 0.16 & 0.16 & 0.16 & 0.16 & 0.16 \\
& DS3 & 0.05 & 0.10 & 0.27 & 0.45 & 0.76 \\
& DS4 & 0.00 & 0.05 & 0.14 & 0.25 & 0.38 \\
\hline \multirow{4}{*}{ Tampa, FL FL } & DS1 & 0.20 & 0.20 & 0.20 & 0.20 & 0.20 \\
& DS2 & 0.03 & 0.03 & 0.03 & 0.03 & 0.03 \\
& DS3 & $3.6 \mathrm{E}-03$ & 0.02 & 0.15 & 0.27 & 0.56 \\
& DS4 & $6.0 \mathrm{E}-05$ & $8.5 \mathrm{E}-03$ & 0.04 & 0.08 & 0.16 \\
\hline \multirow{4}{*}{ Phoenix, AZ } & DS1 & $9.9 \mathrm{E}-03$ & $9.9 \mathrm{E}-03$ & $9.9 \mathrm{E}-03$ & $9.9 \mathrm{E}-03$ & $9.9 \mathrm{E}-03$ \\
& DS2 & $1.4 \mathrm{E}-03$ & $1.4 \mathrm{E}-03$ & $1.4 \mathrm{E}-03$ & $1.4 \mathrm{E}-03$ & $1.4 \mathrm{E}-03$ \\
& DS3 & $1.5 \mathrm{E}-04$ & $1.2 \mathrm{E}-03$ & $7.7 \mathrm{E}-03$ & $1.4 \mathrm{E}-02$ & $2.9 \mathrm{E}-02$ \\
& DS4 & $2.0 \mathrm{E}-06$ & $4.0 \mathrm{E}-04$ & $2.2 \mathrm{E}-03$ & $4.1 \mathrm{E}-03$ & $7.9 \mathrm{E}-03$ \\
\hline
\end{tabular}

654

\section{7. Summary and Closure}

656 In this paper, the performance of an archetype masonry school building was investigated using a 657 tornado fragility methodology. The tornado fragility methodology was explained by introducing 658 a tornado-induced wind load calculation procedure similar to that established by ASCE 7-10 for 
659 straight-line wind loads calculation with several modifications. Since tornado loading still 660 possesses significant uncertainty in its formulation as well as researchers understanding of the

661 phenomena, two alternative approaches, i.e. Approach A and Approach B, are used in this study 662 to calculate tornado-induced wind forces on building surfaces. Approach A uses ASCE 7-10 663 pressure coefficients along with tornado pressure adjustments derived based on the study 664 conducted by Haan et al., while an alternative Approach B is defined in which the tornado 665 pressure adjustments (i.e. $T_{e}$ and $T_{i}$ ) are set equal to 1.0 and the ASCE 7-16 pressure coefficients 666 were used representing the best knowledge in pressure coefficients currently available for 667 straight-line winds.

668 Four damage states were defined for school buildings based on performance of building 669 components; including doors and windows, roof cover, roof structural system, load-bearing wall, 670 and non-load-bearing wall. Then, fragilities for each damage states were developed by checking 671 the performance of damage indicators (i.e. the breach of the predefined performance limit states) 672 which are representative of damage states. Moreover, five variants of masonry construction in 673 five different locations across the U.S. that each have a different tornado hazard were 674 investigated in this study in order to provide fragility functions applicable to different locations 675 throughout the United States.

676 The convolution analysis presented herein provides some insight into why tornadoes have not yet 677 been considered in modern building codes. Inspection of Table 14 shows that the probability of 678 exceeding damage state 4 in 50 years is quite small. However, as the last decade across Tornado 679 Alley and Dixie Alley in the U.S. have shown, it may be necessary to take the consequences into 680 account for these high-consequence low-probability (HCLP) events.

\section{Acknowledgements}

682 The work presented in this paper was supported by the National Science Foundation (NSF) under 683 Grant No. CMMI-1452725. This support is gratefully acknowledged. All views expressed in this 684 paper are those of the authors and do not necessarily reflect the views of the NSF. 


\section{References}

686 [1] Prevatt, D., van de Lindt, J., Back, E., Graettinger, A., Pei, S., Coulbourne, W., Gupta, R., James, D., and Agdas, 687 D. (2012). "Making the Case for Improved Structural Design: Tornado Outbreaks of 2011." Leadership Manage. 688 Eng., 10.1061/(ASCE)LM.1943-5630.0000192, 254-270.

689 [2] Davies-Jones, R. P. (1986). Tornado dynamics. Thunderstorms: A social and technological documentary, E. 690 Kessler, ed., Univ. of Oklahoma, Norman, OK, 197-236.

691 [3] Kosiba, K. A., and Wurman, J. (2010). "The three-dimensional axisymmetric wind field structure of the Spencer, 692 South Dakota, 1998 tornado.” J. Atmos. Sci., 67(9), 3074-3083.

693 [4] Karstens, C. D., Samaras, T. M., Lee, B. D., Gallus, W. A. Jr., and Finley, C. A. (2010). "Near-ground pressure 694 and wind measurements in tornadoes." Monthly Weather Rev., 138(7), 2570-2588.

695 [5] McDonald, J. R., Mehta, C., and Minor, J. E. (1979). "Tornado-resistant design of nuclear power plant 696 structures." Nucl. Saf., 15(4), 432-439.

697 [6] van de Lindt, J., Pei, S., Dao, T., Graettinger, A., Prevatt, D., Gupta, R., and Coulbourne, W. (2013). "Dual698 Objective-Based Tornado Design Philosophy.” J. Struct. Eng., 139(2), 251-263.

699 [7] Mehta, K. C., McDonald, J. R., and Smith, D. A. (1981). "Procedure for predicting wind damage to buildings." 700 J. Struct. Div., 107(11), 2089-2096.

701 [8] Federal Emergency Management Agency (FEMA) (2007). "Multi-hazard Loss estimation methodology 702 Earthquake Model. HAZUS-MH-MR4 Technical Manual.” Department Of Homeland Security, Washington, DC.

703 [9] Federal Emergency Management Agency (FEMA) (2009a). "Multi-hazard Loss estimation methodology 704 Hurricane Model. HAZUS-MH-MR4 Technical Manual.” Department Of Homeland Security, Washington, DC.

[10] Federal Emergency Management Agency (FEMA) (2009b). "Multi-hazard Loss estimation methodology Hurricane Model. HAZUS-MH-MR4 Technical Manual-Appendices." Department Of Homeland Security, Washington, DC. Missiles for Nuclear Power Plants", RG 1.76, Revision 1, March 2007.

[12] Selvam, R. P., and Millett, P. C. (2003). "Computer modeling of tornado forces on a cubic building using large eddy simulation.” J. Arkansas Acad. Sci., 57, 140-146.

[13] Sengupta, A., Haan, F. L., Sarkar, P. P., and Balaramudu, V. (2008). "Transient loads on buildings in microburst and tornado winds." J. Wind Eng. Ind. Aerodynamics, 96(10-11), 2173-2187. J. Struct. Eng., 136(1), 106-116.

[15] Alrasheedi, N. H., and Selvam, R. P. (2011). "Tornado forces on different building sizes using computer modeling." ASME Early Career Technical Conf., Univ. of Arkansas, Fayetteville, AR.

718 [16] Letchford, C., Levitz, B., and James, D. (2015) Internal Pressure Dynamics in Simulated Tornadoes. Structures 719 Congress 2015: pp. 2689-2701.

720 [17] Refan, M., Hangan, H., and Wurman, J. (2014). "Reproducing tornadoes in laboratory using proper scaling." 721 Journal of Wind Engineering and Industrial Aerodynamics, 135, 136-148.

722 [18] American Society of Civil Engineers (ASCE) (2010). "Minimum design loads for buildings and other

723 structures, ASCE 07-10.” Reston, VA. 
[19] Kopp, G. and Morrison, M. (2011). "Discussion of "Tornado-Induced Wind Loads on a Low-Rise Building" by

725 F. L. Haan Jr., Vasanth Kumar Balaramudu, and P. P. Sarkar.” J. Struct. Eng., 137(12), 1620-1622.

[20] Kikitsu, H., Sarkar, P. P., anf Haan, F. L. (2011). Experimental study on tornado-induced loads of low-rise buildings using a large tornado simulator. In Proceedings of 13th International Conference on Wind Engineering.

[21] Simiu, E. and Scanlan, R.E. (1996), Wind Effects on Structures, Third edition, John Wiley \& Sons, Inc., 729 pp.551- 575.

730 [22] McDonald, J. R., and Mehta, K. C. (2006). A recommendation for an enhanced Fujita scale (EF-scale). Wind 731 Science and Engineering Center, Texas Tech University.

732 [23] Amini, M. and van de Lindt, J. (2014). "Quantitative Insight into Rational Tornado Design Wind Speeds for 733 Residential Wood-Frame Structures Using Fragility Approach.” J. Struct. Eng., 140(7), 04014033.

734 [24] Standohar-Alfano, C. and van de Lindt, J. (2015). "Tornado Risk Analysis for Residential Wood-Frame Roof 735 Damage across the United States.” J. Struct. Eng. , 10.1061/(ASCE)ST.1943-541X.0001353, 04015099.

736 [25] Matta, F., Cuéllar-Azcárate, M. C., and Garbin, E. (2015). "Earthen masonry dwelling structures for extreme wind loads." Engineering Structures, 83, 163-175.

[26] Federal Emergency Management Agency (FEMA) (2009c). "Tornado Protection- Selecting Refuge Areas in Buildings. FEMA P-431.” Second Edition, Department Of Homeland Security, Washington, DC.

[27] Zhang, W., and Sarkar, P. P. (2012). Near-ground tornado-like vortex structure resolved by particle image velocimetry (PIV). Experiments in fluids, 52(2), 479-493.

[28] Federal Emergency Management Agency (FEMA) (2010). "Risk Management Series- Design Guide for Security, Washington, DC.

[29] Coulbourne, W. L., and Miller, J. (2012). Performance of school buildings in the Joplin, MO, Tornado. In Structures Congress 2012 (pp. 989-998). ASCE.

[30] Prevatt, D. O., Coulbourne, W., Graettinger, A. J., Pei, S., Gupta, R., and Grau, D. (2013). "Joplin, Missouri, tornado of May 22, 2011: Structural damage survey and case for tornado-resilient building codes." American Society of Civil Engineers, Reston, Virginia.

752 Oklahoma, Tornado of 2013: Performance of Schools and Critical Facilities.” ASCE.

753 [32] Ellingwood, B., Rosowsky, D., Li, Y., and Kim, J. (2004). "Fragility Assessment of Light-Frame Wood 754 Construction Subjected to Wind and Earthquake Hazards.” J. Struct. Eng., 130(12), 1921-1930.

755 [33] Rosowsky, D. V., and Ellingwood, B. R. (2002). "Performance-based engineering of wood frame housing: 756 Fragility analysis methodology." Journal of Structural Engineering, 128(1), 32-38.

757 [34] Federal Emergency Management Agency (FEMA) (2015). "Safe Rooms for Tornadoes and Hurricanes, FEMA 758 P-361.” Third Edition, Department Of Homeland Security, Washington, DC.

759 [35] Dessens Jr, J. (1972). Influence of ground roughness on tornadoes: A laboratory simulation. Journal of Applied 760 Meteorology, 11(1), 72-75.

761 [36] Leslie, F. W. (1977). Surface roughness effects on suction vortex formation: A laboratory simulation. Journal 762 of the Atmospheric Sciences, 34(7), 1022-1027.

763 [37] Natarajan, D., and Hangan, H. (2009). Numerical study on the effects of surface roughness on tornado-like 764 flows. In 11th Americas Conference on Wind Engineering (11ACWE). 
[38] Sabareesh, G. R., Matsui, M., and Tamura, Y. (2012). "Dependence of surface pressures on a cubic building in tornado like flow on building location and ground roughness." Journal of Wind Engineering and Industrial Aerodynamics, 103, 50-59.

[39] Sabareesh, G. R., Matsui, M., and Tamura, Y. (2013). Ground roughness effects on internal pressure characteristics for buildings exposed to tornado-like flow. Journal of Wind Engineering and Industrial Aerodynamics, 122, 113-117.

[40] Liu, Z., and Ishihara, T. (2016). Study of the effects of translation and roughness on tornado-like vortices by large-eddy simulations. Journal of Wind Engineering and Industrial Aerodynamics, 151, 1-24.

[41] Roueche, D. B., Prevatt, D. O., Haan, F. L., and Datin, P. L. (2015). An estimate of tornado loads on a woodframe building using database-assisted design methodology. Journal of Wind Engineering and Industrial Aerodynamics, 138, 27-35.

[42] Kopp, G.A., and Morrison, M.J. (2015). Personal Communication.

[43] Lee, K. H., and Rosowsky, D. V. (2005). "Fragility assessment for roof sheathing failure in high wind regions." Engineering Structures, 27(6), 857-868.

[44] Ellingwood, B. R., and Tekie, P. B. (1999). "Wind load statistics for probability-based structural design." Journal of Structural Engineering, 125(4), 453-463.

[45] Masonry Standards Joint Committee (MSJC) (2011). Building Code Requirements And Specification for Masonry Structures Containing Building Code Requirements for Masonry Structures (TMS 402-11/ACI 53011/ASCE 5-11), Specification for Masonry Structures (TMS 602-11/ACI 530.1-11/ASCE 6-11) and Companion Commentaries.

[46] Kim, Y. S., and Bennett, R. M. (2002). "Flexural Tension in Unreinforced Masonry: Evaluation of Current Specifications." The Masonry Society Journal, 20(1), 23-30.

[47] Precast/Prestressed Concrete Institute (PCI) (1971). PCI design handbook: Precast and prestressed concrete, First Edition, Chicago, IL.

[48] Unanwa, C. and Mahan, M. (2014). "Statistical Analysis of Concrete Compressive Strengths for California Highway Bridges." J. Perform. Constr. Facil. 28, SPECIAL SECTION: Performance of Bridges under Critical Natural Hazards, $157-167$.

[49] Bournonville, M., Dahnke, J., and Darwin, D. (2004). "Statistical analysis of the mechanical properties and weight of reinforcing bars." University of Kansas Report.

[50] Hill, A. T. (2006). "Material Properties of the Grade 300 and Grade 270 Prestressing Strands and their Impact on the Design of Bridges." Master thesis, Virginia Polytechnic Institute and State University.

[51] Cui, X. (2007). "Reliability of Masonry Anchorage.” PhD Dissertation, University of Louisville.

[52] Vann, W. P., and McDonald, J. R. (1978). An Engineering Analysis: Mobile Homes in a Windstorm. Institute for Disaster Research, College of Engineering, Texas Tech University.

[53] Standohar-Alfano, C. D., and van de Lindt, J. W. (2014). "Empirically Based Probabilistic Tornado Hazard Analysis of the United States Using 1973-2011 Data." Natural Hazards Review, 16(1), 04014013.

[54] van de Lindt, J., Graettinger, A., Gupta, R., Skaggs, T., Pryor, S., and Fridley, K. (2007). "Performance of Wood-Frame Structures during Hurricane Katrina." J. Perform. Constr. Facil., 10.1061/(ASCE)08873828(2007)21:2(108), 108-116. 